\title{
Chapter 1: Social trends and new geographies
}

Coordinating Lead Authors ${ }^{1}$ : Marcel van der LINDEN, Elisa REIS

Lead Authors²: Massimo Livi BACCI, Stephen CASTLES, Raul DELGADO-WISE, Naila KABEER, K.P. KANNAN, Ronaldo MUNCK, Adrienne ROBERTS, Johan SCHOT, Göran THERBORN, Peter WAGNER

Contributing Authors ${ }^{3}$ : Tim FOXON, Laur KANGER

(Total Word Count:29914)

${ }^{1}$ Affiliations: International Institute of Social History, Amsterdam ; Federal University of Rio de Janeiro.

${ }^{2}$ University of Florence ; University of Sydney ; University of Zacatecas ; London School of Economics ; Centre for development Studies, Kerala ; Dublin City University ; University of Manchester ; University of Sussex ; Cambridge University ; Catalan Institute for Research and Advanced Studies (ICREA) and University of Barcelona.

${ }^{3}$ University of Sussex. 


\section{Summary ( 2 pages)}

This opening chapter sets the scene for subsequent more detailed analysis of many of the issues raised here. We start by discussing in Section 1 the tension in the current era between humanity’s simultaneously standing at “the peak of possibilities” while also, possibly, facing an abyss due to growing inequalities, political conflict and the ever-present danger of climate catastrophe. We turn in Sections 2 and 3 to the main social and spatial transformations that have characterised the last twenty five years. Again we see advances and regressions, above all uneven and fragile development. These sections set the scene for a consideration of three specific challenges: the tension between capitalism and democracy (Section 4); that between production and reproduction with an emphasis on gender relations (Section 5); and that between demographic change and sustainability (Section 6). We then conclude with a sober appraisal of the prospects for the emergence of viable agents for social transformation (Section 7) before making some general remarks on the challenges and possibilities for social progress (Section 8).

The underlying hypothesis for social progress is that development is, and always has been, contradictory. Poverty amongst plenty, individual advancement versus collective regression and repression intertwined with liberty. If the industrial era emerged through what Karl Polanyi called a "great transformation” are we headed towards, or do we need a 'new' great transformation? We posit a general need for the market to be re-embedded in society if social progress is not to be halted or even reversed.

In terms of the political order we find that the recent transformations of democracy and capitalism have had hugely ambiguous features. It is not wrong to say that the planet is currently both more democratic and more affluent than it was three decades ago. But the ways in which such progress has come about endangers not only future progress, it even puts past progress at 
risk. In political terms, the increasing diffusion of democracy means that more people across the globe have a say on the collective matters that concern them. But under current circumstances, their participation may not be able to reach the kind of decisions that one would understand as collective self-determination. In economic terms, material affluence is being created in unprecedented forms and volume. But, first, this affluence is so unevenly generated and distributed that poverty and hardship do not disappear and are even reproduced in new and possibly more enduring forms. And second, the continuing production of this material affluence may/will endanger the inhabitability of the planet, or large parts of it, even in the short- or medium-term.

We have seen our task as one of offering a complex assessment of the current situation that has not been over-determined by our own political preferences. The positive and negative components of the picture we offer are constitutive of the ambivalent nature of the social progress. We are acutely aware that the world looks very different according to our standpoint geographically, socially and by our social and cultural identity. So we have not posed a false unity in terms of outlook. We consider it useful to pose the key questions as clearly as possible from a collective perspective that includes many diverse disciplinary and subject stand-points.

We also seek to avoid an analysis determined by either a depressed Weltanschauung that sees only catastrophe ahead given recent political developments or what some have called a Polanyian Pollyanna tendency that is emotionally committed to positive social transformation regardless of the evidence. Quite simply, neither pessimism nor optimism are adequate diagnostic tools. This is particularly the case when we turn to the possible agents of the 'new' social transformation we advocate. While we show the decline of 20th-century agents of social change we also try to bring to life the new potential actors for redistribution, social justice and recognition. 


\section{On the peak of possibilities or facing an abyss?}

At the beginning of the $21^{\text {st }}$ century humankind is standing on a peak of capacity and possibilities, following from an unprecedented liberation from what Immanuel Kant called its "self-imposed immaturity”. Many people have more options to express themselves and to build a better collective future. These positive outcomes were generated during the historical Great Transformation in a process of collective action producing public and collective benefits (Polanyi, 1944). A wide range of actors from business, governments, labor movements and social movements from across the globe struggled to construct, expand and maintain spaces for human emancipation. It led to embedded markets which regulated social consequences. This process had an important science and technology component, as the political struggles for human emancipation and appropriation of benefits focused often on scientific and technological change. At the same time, humanity is facing an abyss of disasters, resulting from the unintended and sometimes intended consequences of the Great Transformation and its recent aftermath. New challenges, from steep inequalities to climate change and many others, captured recently in the 17 Sustainable Development Goals, threaten the opportunity for future gains and might diminish opportunities for human flourishing. The Twenty-First Century is in need of a new Great Transformation to embed and regulate markets yet again in social relations which in this second round should include our relationships with the environment.

Human history cannot be summed up in linear trend lines, as it is full of cycles, contingent shocks, unintended and unexpected consequences, and reversals, as well as being globally diverse. The history of the past, say 200, years looks very different depending on from what part of the social world one looks at it. Social science and historiography need to fully recognize and take into account this diversity, with its important implications for ambiguous and contested meanings of concepts like progress, development and evolution. However, human history is also not reducible to a series of random events. Patterns are discernible, and some social changes do 
appear most likely to be irreversible. For instance, the abolition of plantation slavery, of patrimonial states, of apartheid, or of certain aspects of male dominance (where it has occurred) seem to have a high threshold of reversibility. Perhaps this indicates that the world situation at the dawn of the $21^{\text {st }}$ century is best approached from a perspective that focuses on the development of patterns.

\subsection{An ambivalent human grasp of the world: a few snapshots}

The drive to control society and nature as embedded in modern science and technology has taken a new leap forward in recent times, comparable to the two industrial revolutions, of coal and steam and of electricity and the combustion engine. Even though social processes are irreducible to any technological determinism, scientific and technological changes do have a great social impact. We are living in a world of rapid and possibly accelerating technical change, driven by a quest for further control of society and nature. This quest is clearly visible in two major breakthroughs of knowledge and its applications. One is springing out of electronics, with electronic programming, communication, and monitoring. It has created not only the internet, search engines into gigantic data collections, e-commerce, and smart phones, but also new forms of design, artificial intelligence - now capable of beating human masters of the most difficult games, robotics, and driverless cars. The other is a biological revolution, following the discovery of the genetic code, the mapping of the human genome, the development of genetic manipulation and cloning, and the beginning of applications from stem cell research. However, the cognitive and technical advances of humankind cover a broader field. Our knowledge of space has expanded exponentially, from outer astronomic space to inner space navigated by nano technology. New energy sources have been created, by nuclear, solar, wind, wave, and fracking technology, the implications of which also illustrate the ambiguity of human creativity, the first has already proved its riskiness, the last being widely regarded as dangerous. Such ambivalent developments are also visible in other areas. 
Between 1980 and 2011 income per capita increased 1.8\% p.a. (in constant prices and at global purchasing power parity), compared to $1.2 \%$ p.a for $1870-1913$, and $2.9 \%$ p.a for $1950-72$. The increase has been very unequally distributed, but from 1999 to 2012 about 840 million people got out of extreme poverty (defined as less than US\$1.90 a day in income or consumption at purchasing power parities), of whom around 800 million in Asia, while extreme poverty still increased in sub-Saharan Africa (by 13 million) (Cruz et al. 2015:6). Massive middle class aspirations of consumption are arising, most strongly in Asia (ADB 2011), but also in Latin America, and at least discernible in Africa. The improvement of the lot of poor people in big poor countries was large enough to produce, in the first decade of this century, some decline of income inequality among the inhabitants of the world, after a period of high plateau stability since the mid-20 $0^{\text {th }}$ century, and 150 years of continuous increase of inequality before that (Milanovic 2016: 120ff).

The biomedical revolution has led to a qualitative leap in humankind's self-emancipation, particularly in women's increased autonomy with regards to their bodies, through control of reproduction, by effective contraception and safe abortions where they are available. ${ }^{4}$ In some parts of the world - Sub-Saharan Africa being the main exception - women have gained greater control of their fertility. On a world scale, the total fertility rate is now down to 2.5 child per woman. Above is sub-Saharan Africa (more than 5), and the Arab states at 3.5 (UNFPA 2015:127). Humans have also learnt to repair their bodies, by organ transplants, nanotechnological implants, and by stem-cell transfers. We have become able to change our sex, as well as to change our appearance through cosmetic surgery. However, human mastery of

\footnotetext{
${ }^{4}$ According to a survey of 196 countries based on 2013 United Nations data, approximately $26 \%$ of countries only allow abortions to save the life of the mother, an additional $42 \%$ allow abortion when the mother's life is at risk and one other specific reason applies (i.e. the pregnancy was the result of rape or incest or because of fetal impairment) and 3 in 10 countries allow them for any reason (before a certain point). Six countries do not allow abortions under any circumstances (Theodorou and Sandstrom 2015).
} 
themselves does not extend to vulnerability to infectious diseases, as the epidemics of AIDS, SARS, Ebola, Zika, and as the return of old viral enemies thought defeated for good, like tuberculosis and polio, have recently demonstrated.

For all regions of the world, the United Nations Development Programme’s Human Development Index has continuously improved during the 1990-2014 period, and between development groups of countries there has also occurred some convergence, at a snail's pace, as the index increase has been consistently smaller the higher the degree of development (UNDP 2015:215). Life expectancy (at birth) in the world increased from 64 to 71 years, with some convergence among regions and income group countries (WHO 2015: 52).

Global connectivity has also enormously increased, thanks to electronic media. Satellite television spreads worldwide, not only images and entertainment - which bring people together in some sense - but also information, including different perspectives and kinds of information. Social media, such as YouTube, Facebook, or Twitter are creating something of a global public. The United Nations, and its specialized agencies, have increasingly come to constitute a global agora - instead of a Cold War dueling place - where global development goals and climate change are being seriously at least talked about.

The last third of the twentieth century saw two epochal transformations of human social life, not universal, and far from complete, but in a world historical perspective of immense importance, which should not be diminished by myopic familiarity. The ancient hierarchies and exclusions of gender and race were shaken in their foundations. In some parts of the world they crumbled, while remaining as ruins, in others they cracked but kept standing, while opening fissures and crevices of evasion. Through all the persistent, in some respects aggravating, divisions and conflicts among humankind, to which we shall turn below, the undermining of institutionalized racism, sexism, and male domination, where it has occurred, signals a profound process of social inclusion. They were processes of existential equalisation, by which previously 
discriminated, marginalized, and/or excluded categories of people have been, at least officially, recognized as equal members of society.

The United Nations’ Declaration of Human Rights proclaimed in 1948: “Men and women of full age, without any limitations to race, nationality or religion, have the right to marry and to found a family. They are entitled to equal rights as to marriage, during marriage, and its dissolution. Marriage shall be entered into only with free and full consent of the intending spouses.” (Article 16) But this right was then embodied only in Scandinavian (and with a foreign nationality qualification Soviet) marriage codes and practices (Therborn 2004: 75 ). Starting in the late 1960s and gathering momentum in the 1970s, male dominance and bans of inter-religious or inter-racial marriages have been dismantled in large parts of the world, though not in most Muslim countries. Male dominance and sexism are still strong in India, several parts of Asia, and in sub-Saharan Africa. More broadly, according to the World Bank's research, numerous legal and regulatory barriers prevent women from being able to interact with public authorities and the private sector, to manage, control and inherit property, to access paid employment and credit, and to be protected from domestic violence and sexual harassment (World Bank 2013). Almost 90\% of the 143 countries surveyed have, for instance, at least one legal difference restricting women’s economic opportunities (World Bank 2013: 8). Yet, signaling progress, women's right to education and to participation in the public sphere are now very widely recognized. The Third of the Millennium Development Goals, gender parity in education at all levels, was reached in the 'developing' world as a whole, although with respect to tertiary education overall parity hid under-representation of males in East Asia, Latin America, and North Africa , and of women in South Asia and sub-Saharan Africa (UN 2015a:29).

The military smashing of the racist horrors of Nazism did not mean an end to institutionalized racism. Apartheid in South Africa actually developed after 1945. Racial 
segregation stayed as a rule of the American way of life until the second half of the 1950s. 'Keep Australia White’ was official Labour party policy until the early 1970s. The Civil Rights movement in the United States finally brought the right to vote to all African-American citizens in the late 1960s, and in the early 1990s the apartheid regime crumbled. Indigenous peoples of the settler states of the Americas and Oceania have been officially racially rehabilitated in the beginning of this century. The historical sea-change is highlighted by the fact that in the 1990s South Africa got a Black President, and in the 2000s Bolivia elected a President of nativeAmerican descent for the first time, and the United States an African-American.

Racism and misogynous sexism have certainly not disappeared from the planet, but the huge changes of the last half-century provide an important platform for meeting the challenges of today. The last decade has also witnessed a retreat of another sexism, homophobia, with a widespread, if by no means universal, recognition of the right to same-sex marriage. Since the first law allowing same sex marriage in modern times was passed in the Netherlands in 2001, it has been recognized in almost two dozen countries - though no country in Asia and no country other than South Africa on the African continent recognizes this right.

Less epochal than the partial dismantling of sexism and racism but also inclusive, was the late $20^{\text {th }}$ century spread of democracy, which may be taken as an institution of political inclusion. Democracy had its first breakthrough in the aftermath of World War I, but has had a dramatic twentieth-century history, with brutal reversals, violent contests, fraud, and difficult processes of re-democratisation. For the time being, democracy appears more widespread and more stable than ever before, if not everywhere more trusted. In the late 1980s- 1990s dictatorships of very different kinds fell or imploded for very different reasons, all over the world, though far from everywhere. A global wave started in Asia - Philippines, South Korea, Taiwan - continuing in Latin America and Eastern Europe, to reach sub-Saharan Africa.

In the struggles against political exclusion and repression there developed a discourse 
which has come to constitute still another dimension of inclusive social developments, a discourse of human rights. While not seldom instrumentalized in geopolitical conflicts, human rights constitute a principle of universal inclusion. The anti-slavery campaigners of the 19th century and before used the notion, but for a very minimalist human right, of not being enslaved. Now it is being used in reference to a large register of rights for each and everybody.

Very probably, new, unexpected challenges to human societies will appear later in this century, and there is already quite a number of difficult problems confronting human wisdom and creativity. But one issue is most likely to raise a paramount challenge to humankind of the $21^{\text {st }}$ century: the ecological unsustainability of the current development path. Climate change and the threats from global warming, and from other human-made environmental hazards are issues generated by choices made in the past, such as the unlimited exploitation of fossil fuels.

While waiting for the fatal meltdown of global warming, other environmental problems are piling up, largely as effects of unplanned urbanization. Exposure to air pollution is increasing rapidly, with known dire effects, although no reliable mortality data seem to be available. From 2000 to 2013 the number of people in low and middle income countries exposed to polluted air above the World Health Organisation's guidelines increased by 900 million (Cruz et al. 2015: Figure 20). The number of people affected by natural hazards annually quadrupled between 1974-84 and 1996-2005, largely because the number of people living in flooding, cyclone or other disaster-prone areas has increased (Brecht et al. 2013:2-3). The recurrent smogs of Beijing and Delhi, and the annual inundations of Jakarta illustrate acute problems already in place.

Climate change challenges the whole world. In what measure can recent scientifictechnological revolutions yield adequate cognitive-technical means to meet the challenge? Clearly, there has been a major boost for climate science, which has deepened its understanding of the extremely complex processes involved, although it too often ignores social dimensions. New sources of energy have been developed, and the concept of "sustainable development" has 
been inserted into urban planning and national political discourse.

The crucial issues seem to be two. First, how are the costs of limiting global warming to be allocated globally? An important part of this question is, to what extent do the polluters of the first industrial revolutions have to pay for past sins? To what extent is some sort of progressive international sharing of the global costs realistic? Another aspect is: who shall pay for a stop or strict limitation of fossil fuels production, only the coal and oil producers themselves? And how can the loss of jobs in the fossil sector be compensated for? Secondly, and decisively, what social forces can be envisaged to successfully re-direct forms of consumption and re-evaluate preferences, in the rising cities of Asia as well as in the North Atlantic area, which may be necessary for adopting a path of environmentally sustainable development?

The global human rights movements of the late $20^{\text {th }}$ century did spawn planetary ecological awareness and movements but not much of a political force. Environmentalist movements have emerged all over the world, but nowhere yet has any been near hegemony. How shall the climate scientists be able to convince national power holders with their conflicting national interests? The political sociology of eventual adequate and effective climate policies has to be clarified and laid out.

The scientific and technological advances of recent times have indeed increased human emancipation, but mainly of humans as individuals, whether as managers, designers, communicators, doctors or patients, little with respect to mastering collective problems and in providing common goods - Wikipedia is a rare exception. Technologies are usually developed to cater individual needs, not collective needs (individual cars instead of public transportation, individually owned washing machines, individual instead of collective cooking, etc.). Except for a brief period in 1996-2004, technological innovations have not even increased labour productivity, at least not in the leading economy of the world, also the centre of the electronic and biological revolutions (apart perhaps from productivity in the service sector). Rather, 
productivity growth has slowed down, after 1970 and again after 2004, and it has been forecast to decelerate further up to 2040 (Gordon 2016: 522ff; 637ff).

The Great Inclusions, of race, and gender, and sexuality, are most likely to stay, and rather likely to move forward - even during the US acceleration of economic inequality, the income position of women and of African-Americans tended to approximate, somewhat, that of their male/White superiors (Lindert and Williamson 2016: 222ff). However, in Europe and USA, in particular, they are getting overwhelmed by new rifts in social cohesion caused by rising intranational economic inequality, and by mounting divisions between the winners and the losers of national borders wide opened to trade and migration. The complex political repercussions of this have been, on one hand a shake-up of the political landscape, and policy stalemates, on the other. In spite of widespread anger as well as social scientific concern and criticism, not a single democracy has been able to do anything to change what has been called "the economy of 1\%" (Oxfam 2016). Latin America's exceptional $21^{\text {st }}$ century decade of equalisation is breaking down in economic crisis and political acrimony.

The combination of severe planetary environmental challenges and galloping intra-national inequality is explosive. Because ecological issues affecting all humankind will require panhuman cooperation, which in turn is deeply imperiled, if not impossible, under conditions of mounting inequality and exclusion, with the diverging priorities and increasing mistrust the latter tend to generate. As the one per cent are the ones least likely to be affected by climate adversities, a supranational alternative of an adequate response put together by the increasingly interwoven global upper class appears even less likely. The significance of the (slight) overall global economic equalisation due to the high growth of China, India and others, is diminished by these countries being internally more unequal and divided than both the United States and Europe. Current inequality is making it very difficult for humankind to make full use of its peak of capacity and possibilities in meeting the planetary challenges of this century. Economic 
resources are appropriated by a few, as underlined by the fact that 62 individuals have amassed as much wealth as the bottom half of humankind, 3.6 billion people (Oxfam 2017:11), in other words, on average the former own 58 million times more than the latter. Stark inequalities tear societies and polities apart, which leads to bitter and violent conflicts or 'at best' socio-political paralysis, rather than to resolute collective action.

Inequality is taking on very sinister implications, some returning, others new. These implications are likely to get increasing pressure from the coming upheavals of the world of work in the wake of coming automation. Inequality and poverty have to be seen as largely located inside increasingly hazardous environments, on barren vulnerable land, in peripheral urban areas, particularly vulnerable to storms, flooding, and landslides, in rich countries (USA: New Orleans), as well as in poor countries (Tschakert 2016). At the other end, the richest ten per cent of humanity produce about half of $\mathrm{CO}_{2}$ emissions of the world.

It has been known to scholars for some time that there has been a historical mid- to late $20^{\text {th }}$ century tendency for the intra-national social gap of life expectancy in Europe to widen, but mainly because longevity among the privileged classes has grown faster. However, in recent years, instances of an absolute rise of mortality and decline of life expectancy have been found, e.g., among US White high-school drop-outs (Case and Deaton 2015), and among the poor and the unemployed in Finland (Tarkiainen et al. 2012). The economic inequality tendencies have linked up with the inclusion of women into the labour force in an unexpected way, generating a new process of inter-generational exclusion. While coupling between well-educated, wellearning men and women is becoming more stable, with more time and money invested in their children, the opposite is occurring at the end of the precariat and the unemployed. There more family instability and more children growing up in relative poverty with a single parent under stress prevails (Putnam 215).

Today’s humanity has an immense responsibility. It has inherited unprecedented capacities 
and possibilities, of knowledge, technology, communicability, and with much of an escape from the ancient racial/ethnic and gender confinements and divisions of humankind. It also is facing its share of the perennial problems of humankind, of finding its livelihood, staking out a path to a good life, resolving conflicts and issues of injustice, coping with the dialectics and the unintended consequences of evolution, the dialectics highlighted by, e.g. the rise of mortality among the marginalized in the midst of the biomedical revolution. On top of that humanity has to confront the unprecedented challenge of climate change and of creating sustainability amidst an inhabitable planetary environment.

We now address important recent social and spatial transformations and then analyse in detail three central tensions in more depth which need to be confronted in the 'Next' Great Transformation.

\section{Recent social transformations}

Of all the complex issues, the one that may be said to loom largest over the idea of progress is the continuing reality of 'poverty amidst plenty'. Over the past four decades, there has been an unprecedented increase in material income, wealth and resources on a global scale along with the persistence of enormous deprivation for not less than a third of human kind. Even when some material advancement has taken place for sections of the previously deprived segments of people, the role of structures of inequality can be seen as central to this paradox of poverty amidst plenty. What should be underscored as worrying is the trend towards increasing inequality in a whole range of arenas that challenges the idea of social progress.

It is difficult to measure the development of inequality reliably. Central indicators of countries' success, such as the Gross Domestic Product (GDP), have many significant shortcomings (Fleurbaey and Blanchet 2013). The building of alternative indicators (composite indicators, subjective well-being indexes, capabilities, and equivalent incomes) is under way, but 
still underdeveloped. Although the available figures suggest a precision that does not really exist, they nevertheless reveal significant trends. They tell us, for example, that between 1970 and 2013, global gross output of goods and services considerably exceeded the population increase, or in other words, that the output per person was rapidly growing. The extraordinary process of growth over the last decades is beyond doubt, with the sole exception of the so-called transitional economies that witnessed a catastrophic fall in their income between 1980 and 2000 but most notably during the last decade of the twentieth century.

The overall geography was marked by interesting, if not drastic, changes across the same period. The share in world output of the developed rich countries decreased from 70 per cent to 59 percent after peaking to close to 79 per cent in between. This decline was due to the ability of the 'developing' countries to increase their share from 17 to 37 per cent. The so-called BRIC group (Brazil, Russia, India, China) claims a share of a little more than one-fifth of global Gross Domestic Product, largely contributed by China. But there has been a more careful documentation of 'developing' countries that demonstrated a greater potential for growth and development with significant shares of population beyond the BRIC group and they are referred to as 'The Next 14' (Nayyar 2013). In the group of Next-14 are Argentina, Brazil, China, Chile, Egypt, India, Indonesia, South-Korea, Malaysia, Mexico, South Africa, Taiwan, Thailand, and Turkey. This group comprises a little more than half the global population. Although this group is an analytical construct of economically dynamic countries with a significant share of world population, they are not a formal group in the international arena. Yet the emergence of these select 14 countries should count as a new trend in the global economic scenario since the industrial revolution, despite the recent deceleration in economic dynamism in some of them. This growth is the end result of a whole range of developments equally unprecedented. Global trade increased tremendously from $\$ 4.37$ trillion to $\$ 45$ trillion or from close to 36 to 60 per cent of the world income between 1980 and 2013 creating a vast web of trade interdependencies 
across countries in different continents. Not only did foreign direct investment increase by 3.4 times between 1990 and 2013; through so-called “arms-length outsourcing” firms from 'developed’ countries increasingly contract out some or all of their production to nominally independent suppliers in 'developing' countries while retaining control over the production process.

\subsection{History matters}

The global geography of economic wealth has changed to a significant extent but given the highly unequal starting point of the players as well as the change in demographic trends the shift is relative. This is reflected in per capita income that could be roughly portrayed as a sign of economic clout if not self-perceived human welfare. Two groups of countries - the so-called low income and the low middle income 'developing' countries - lost out in this process along with the transitional economies. Losing out implies that a country's per capita income as a share of the average per capita income of the 'developed' countries is lower in 2013 as compared to 1970. For example, per capita income of Zimbabwe was 12.2 per cent of the average per capita income of 'developed' countries in 1970; it fell to 2.03 in 2013 leading to a wider gap than when it started.

What should be seen as a major setback is the fact that all the countries in the Low Income Developing Country group have been losing out in terms of this inequality measure despite the fact that 15 out of the 26 countries have managed to perform well during 1990-2013. This group has the highest incidence of various forms of human deprivation and are classified as countries with a 'low human development index' by the UNDP. The second group of Lower Middle Income 'developing' countries has a less pessimistic record but with two-thirds of the countries losing out.

The results are better for the next group of Upper Middle Income 'developing' countries that includes China and other east and south-east Asian countries. China is a star performer here. 
Yet it has to go a long way to catch up. The exercise shows that the 1970-90 period, especially the 1980-90 was a period of losing out for a majority of the 'developing' countries. The poorer a country, the greater was its decline relative to the developed country average (UNCTAD 2015). The crash in commodity prices and unfavourable terms of trade could be counted as some of the reasons for this relative decline. Given the remarkable recovery since 1990, it would be tempting to attribute that to the new regime of globalisation. But the remarkable growth momentum within the group of 'developing' countries, especially the Next 14, and consequent rise in commodity prices and a greater flow of migrant labour within the global south need to be factored here. In short, there has been a great degree of economic interdependency among ‘developing’ countries since 1990.

For the transitional economies the end of the 1980s witnessed not only a political turmoil but also a concomitant collapse in economic growth. Most of them are on their way to recovery but there is a long way to close the gap given the fact that they have seen a sharp decline in per capita income compared to the 'developed' countries.

The best performers are the group of 'developed' countries consisting mostly of the 'old rich’ i.e. the USA, Western Europe and Japan. To a very large extent they now have a much shorter gap with the average per capita of their own group than four decades ago. What this shows is the convergence of income among the rich countries. But the lesson from the point of inequality is that the pre-existing huge gap between the poorest and the richest group of countries has further widened.

The question of inequality is being discussed by scholars as well as several global civil society organisations and movements (see e.g. Piketty 2014, Oxfam 2017). However, inequality has many dimensions and a focus mainly on the economic one is bound to be too limited to understand the many social and political consequences of inequality. Therborn (2006) classifies these dimensions broadly as (a) Resource inequality, (b) Vital inequality, and (c) Existential 
inequality. Resource inequality refers to inequality in income, assets, and in skills. Vital inequality refers to bodily health as well as a sense of wellbeing that transcends mere bodily health. Existential inequality is perhaps the most important one when it comes to social and political tensions and conflicts both within and across countries. It has to do with dignity or its absence, freedom, respects, rights and sense of participation. Given the fact that vital inequality refers to one dimension of human capability, it appears to be more appropriate to call it 'capability inequality’ by bringing in education including skills.

\subsection{Enhancing capabilities}

Despite the enormous increase in wealth and income in the world as well as technological developments that can fulfill the basic requirements for a decent and dignified human existence, there are considerable deficiencies that impede social progress such as the opportunity to access basic capabilities namely, education and health - to mention the most important ones. Some progress seems to have been made but the deficits are quite large and even formidable. Illiteracy may not be the most important

problem now but the absence of a minimum of education is. Consider the proportion of people without at least a secondary level of education. It is a huge deficit in most 'developing' countries. In many poor countries only a small fraction has attained this rather modest threshold in an age of digital communication, information sharing and knowledge production. A similar picture emerges when the question of basic health conditions is flagged. There are several indicators but the robust one of Infant Mortality Rate (IMR) would indicate the state of affairs in most 'developing' countries. While the High Human Development countries report an average IMR of 5 deaths aged under one year per thousand births, it is (at 64) 13 times in Low Human Development countries (see UNDP 2014).

There is a direct link between the absence of basic capabilities and income poverty. Low capabilities lead to considerable lower opportunities for gainful employment. Those with low 
capabilities also have very low assets or are asset poor, a fact that also reduces or denies opportunities for gainful self-employment. We highlight the importance of addressing capabilitybuilding and enhancement as a precondition for eliminating poverty and creating opportunities for broad-based growth. New and emerging inequality has to do with the development of Information and Communication Technologies (ICT). ICTs have been associated with increased possibilities for entrepreneurship, economic prosperity, democratisation, political participation, social capital, access to plurality of information, better education, sustainable development and the like. However, access to ICTs continues to be highly unequal with 'developed' countries having a considerable lead. Moreover, this global digital divide seems to be relatively durable: for example, in comparison to 2010 the ICT Development Index (IDI) increased by 0.92 points for developed and 0.89 points for 'developing' countries but only 0.56 points for the Least Developed Countries (ITU, 2015: 56). These countries risk becoming the "black holes of informational capitalism" (Castells, 2010), largely bypassed by global flows of information, power and wealth.

The developmental significance of the digital divide is contested. Accounts of the rapid spread of mobile phone technology in Sub Saharan Africa has led to speculation about 'skipping stages' of development. For others the techno-economic vision of globalizing ICTs misses the nature of development-underdevelopment and is insufficient (and even counter-productive) to address uneven global development.

The "digital divide" does not only pertain to differences between countries but is also reflected in other measures, e.g. gender, education, income and place of residence with males, highly educated, wealthy and urban citizens having better access than females, less educated, poor and rural population.

\subsection{Intersecting inequalities}


Along with the material inequalities captured by such measures as income, wealth and so on, ('what you have') there are other forms of inequality that revolve around identity ('who you are'). The inequalities at work here are the product of social hierarchies which define particular groups in a society as inferior to others on the basis of devalued aspects of their identity. Groupbased inequalites thus resonate with the idea above mentioned of 'existential inequality'. Considering the multi-dimensional nature of inequality further involves consideration of how particular differences and divisions are produced through social structures and power relations. Gender relations, for instance, cannot be reduced to differences between 'men' and 'women', but rather reflect differences in the ways in which categories of 'masculine' and 'feminine' have been established and maintained, how the former is privileged over the latter, and how different types of women and femininities are valued differently, as are different types of men and masculinities (Connell 1995). These hierarchies are created and maintained through norms, values and practices which serve to routinely disparage, stereotype, exclude, ridicule, and demean certain groups relative to others, denying them full personhood or the right to participate in society on equal terms with others.

It is quite possible to face discrimination on the basis of your identity without being materially deprived. Gender and sexual identity, for instance, cut across class so that to be a woman or LGBTQ (lesbian, gay, bisexual, transgender, queer) does not necessarily mean being poor. However, the most entrenched forms of inequality, those that have persisted over generations, occur when group-based inequalities intersect with material deprivation. In South Asia, members of the lowest castes and tribal groups have long been over-represented among the very poorest. Indeed their disadvantage has remained unchanged on a range of indicators of wealth, capabilities and wellbeing (Kannan 2014 and 2016). In Latin America, it is generally Afro-descendents and indigenous peoples who have historically made up the very poorest sections of the population. In South Africa, the greater poverty of Black Africans persists, 
despite the rise of a black middle class, although the apartheid system has been formally dismantled. In China and Vietnam, it has been historically their ethnic minorities who have made up the poorest populations. In most of these cases, gender intensifies the disadvantage of those at the bottom of the economic hierarchy so that women from these groups tend to be poorer than the rest of the population, to earn less and to have lower levels of wellbeing and capabilities (Kabeer, 2015)

\subsection{Durable inequalities}

With regard to all the dimensions of inequality, one furthermore needs to ask how 'durable ' they are and how difficult it is to overcome them (Tilly 1999). Taking both 'developed' and 'developing' countries, the most entrenched form of inequality of all kinds often is the one based on social identity such as race, caste and ethnicity. More often than not it also reflects a class dimension with most of the excluded group of people experiencing the highest incidence of economic deprivation. It is so well entrenched that no coherent response to it has yet been undertaken from a global point of view. It is durable because it is based on distinctions between categories of human beings. Formation of categories of the types mentioned above has deep historical precedents. For Tilly categorical inequality serves the objective of maintaining control over surplus generation. This is based mainly on exploitation and opportunity hoarding. Gender inequality could be said to upset this type of categorical inequality because of the disadvantaged position of women viz-a-viz men in the categorical groups mentioned here. However, this need not mean an overwhelming presence of gender inequality over this form of categorical inequality. What it does in fact is adding to the complexity of this inequality by a further layering of the gender dimension. That is to say, the inequality between the bottom group and the top group could be a more entrenched one than the inequality between men and women in each group or in general. Sometimes, gender inequality can be a mixed one especially at the top where women have come to attain a higher status than men as in the case of life expectancy or, 
in some contexts, average years of schooling.

Although inequality based on social identity has been a hallmark of most societies, research on this dimension is not as abundant as in the case of economic inequality between income groups. For some countries such as the United States (and to some extent India), a considerable amount of research has been done on the social inequality issues of the kind depicted here. In general, the evidence in the United States suggests a huge gap between the 'whites' and 'blacks' in the United States which in certain cases seems to be widening especially during periods of crisis (Levine et.al 2001). There is also evidence on widening wealth disparity between 'whites' and 'blacks' and 'whites' and 'Hispanics' (Kochhar and Fry 2014).

A similar picture of categorical inequality that has been well entrenched in terms of its durability is something that is also being faced by many ‘developing’ countries. India is a prime example of this durable inequality. Although several religions co-exist the one dominant is the Hindu religion and its caste system that has a deep hierarchical structure in a broad sense of upper, middle and bottom. The bottom place is occupied by those classified as Scheduled Castes (who prefer to call themselves as dalits and constitute the ex-untouchable segment) and Scheduled Tribes (who prefer to call themselves adivasis or original inhabitants). In fact, the hierarchical structure has remained unchanged in a whole range of indicators of wealth, capabilities and wellbeing (Kannan 2016).

\subsection{The increasing power of the multinational corporations}

Nation-states and their citizens are the principal focal points in the debates about global inequality. However, the increasing economic power of the multinational corporations (MNCs) should be seen as one of the principal factors contributing to the enormous inequality between the top and the bottom. One of the manifestations of this power is the increasing monopolisation of finance, production, services and trade, leaving every major global economic activity to be dominated by a handful of large multinational corporations. In the international political 
economy, large industrial and financial corporations have become, more than ever, the central players. Through mega-mergers and strategic alliances, this fraction of capital has reached unparalleled levels of concentration and centralisation: in 2014 the top five-hundred largest multinational corporations acquired US\$ 31.2 trillion in revenues (Fortune, 2015), equal to 40\% percent of the world’s Gross Domestic Product (World Bank, 2015). Overall, industrial and financial capital has undergone a profound restructuring process where:

First, is the ascendancy of finance capital over other fractions of capital. Finance capital began this ascendancy with the onset of an overproduction crisis in the late 1960s, when German and Japanese capital recovered from the devastation of World War II and began to compete with U.S. capital on world markets (Brenner, 2002). With the lack of profitable investment in production, capital began shifting toward financial speculation based on an unprecedented reserve of fictitious capital (McKinsey, 2013). Another response to the overproduction crisis was the reduction of labour costs through global labour arbitrage. Moreover, with the downward pressure on real wages, a finance-led debt explosion sustained purchasing power for the realisation of production. The end result has been the financialisation of the capitalist class, of industrial capital, and of corporate profits.

Second, we see the configuration and expansion of global networks of large industrial and financial corporations as a restructuring strategy, which -through outsourcing operations and subcontracting chains- extend parts of their productive, commercial, financial and service processes to the Global South in search of natural resources and abundant cheap labour. The strategy of global labour arbitrage - that is the substitution of high-wage workers in 'developed' countries with like-quality, low-wage workers in the 'developing' countries -is exemplified by the export platforms that operate as enclave economies in peripheral countries (Delgado Wise and Martin 2015). This turn toward global production chains has been impressive: '[the] top one hundred global corporations had shifted their production more decisively to their foreign 
affiliates [mainly in the South], which now account for close to 60 percent of their total assets and employment and more than 60 percent of their global sales' (UNCTAD, 2010). Moreover, an outstanding feature of contemporary global capitalism is the degree of network articulation and integration with the operations of large multinational corporations dominating international trade: at least 40 percent of all global trade is associated with outsourcing operations, including subcontracting and intra-firm trade, an estimated 85 million workers directly employed in assembly plants in the Global South, and over 3500 export processing zones established in 130 countries. This restructuring strategy has transformed the global geography of production to the point that now most of the world's industrial employment (over 70 percent) is located in the Global South.

Third, the restructuring of innovation systems through the implementation of mechanisms such as outsourcing (including offshoring) the scientific and technological innovation process, which allows multinational corporations to benefit from the research of scientists from the Global South. This restructuring reduces labour costs, transfers risks and responsibilities, and capitalizes on the advantages of controlling the patent process. Four over-arching aspects characterise this restructuring process:

a) The increasing internationalisation and fragmentation of research and development activities. In contrast to the traditional innovation processes occurring 'behind closed doors' in research and development departments internal to large multinational corporations, this trend is known as open innovation;

b) The creation of scientific cities—such as Silicon Valley in the United States and the new 'Silicon Valleys' established in peripheral or emerging regions, principally in Asia—where collective synergies are created to accelerate innovation processes (Sturgeon, 2003);

c) The development of new methods of controlling research agendas (through venture capital, partnerships and subcontracting, among others) and appropriating the products of 
scientific endeavours (through the acquisition of patents) by large multinational corporations;

d) The rapidly expanding highly-skilled workforce - particularly in the areas of science and engineering - in the Global South is being tapped by MNCs for research and development in peripheral countries through recruitment via partnerships, outsourcing and offshoring.

Fourth, the renewed trend toward extractivism and land grabbing steered by the continuing over-consumption of the world's natural resources and the expansion of carbon-based industrial production. The increasing urbanisation and industrialisation in Asia, particularly China, has increased the demand for raw materials, which, combined with the transformation of commodities from a hedge asset to a speculative asset for finance capital, created a commodities boom since 2002 that has recently declined with the deaccelerating Chinese economy. High prices for commodities have driven the exploration for non-renewable natural resources into remote geographies, deeper into the oceans and the jungles, in the process exacerbating social conflicts over land and water. This new extractivism has increased environmental degradation, not only through an expanded geography of destruction, but also by global extractive capital's strategy of environmental regulatory arbitrage (Xing and Kolstad, 2002). Moreover, despite 25 years of increasingly dire warnings from the Intergovernmental Panel on Climate Change, the global consumption of fossil fuels continues to rise, 'triggering a cascade of cataclysmic changes that include extreme heat-waves, declining global food stocks and a sea-level rise affecting hundreds of millions of people' (World Bank, 2012). Given that the revenues of some of the world's most powerful and profitable multinational corporations depend on fossil fuel consumption, this pattern will likely continue, setting the world on a path toward a deepening ecological crisis.

The above trends are associated with the unprecedented commodification and private appropriation of tangible (through unrestrained extractivism and land grabbing) and intangible (through an exponential growth of patents and their overwhelming appropriation by 
multinational corporations) common goods. The cumulative effect is that contemporary capitalism is facing a profound multi-dimensional crisis (financial, economic, social, ecological crises) that undermines the main sources of wealth creation-labour and nature-to the point that it can be characterized as a civilisational crisis with a potentially catastrophic outcome.

\section{New spatial configurations}

The complex social transformations of the global order described in the previous section also have a spatial dimension. The Polanyi-inspired focus on the expansion of the free market and the related social countermovement to protect against the disembedding it creates is now widely accepted. However, a separate, sometimes unrelated, focus on the political economy of scale and the underlying notion that "space is a social construct" (Lefebvre 1991) also needs to be part of our reflexive lens. In brief, social relations cannot be understood without a firm focus on how they are grounded in particular places.

\subsection{Time-space compression}

Social and economic landscapes are not passive spectators, but are actively struggled over. A central notion here would be that of a "social-spatial dialectic" to underpin our analytical focus. This would direct us towards a reflexive and complex view of the contemporary order (and its possibilities for transformation) which understands social relations and spatial relations as mutually constructive. The spatial is thus not a mere reflection of social relations and requires explicit treatment here. We do this by critically examining the process(es) known as globalization and its impact.

Globalisation as a 'way of seeing' the world around us had become dominant amongst its supporters and detractors alikeduring the early 1990s. Then it was seen as epoch-making and signaling a transition to a brave new world, though with the crisis of 2008-9 many argued that globalisation had 'gone too far'. At first analysis was dominated by the optimistic globalisation 
enthusiasts for whom the new communication technologies signaled a major shift to a new order in human history. Globalisation in reality was/is more complex and contradictory than any technological determinism will allow for. Nor is it totally novel. We need to note that the phenomenon is not new, as the first wave of internationalisation took place from around 1860 to 1914. And yet the world has changed dramatically compared to the post-war order and its particular social-spatial dynamic.

Globalisation needs to be understood as a set of inter-linked economic, political, social and cultural processes. Its overarching theme has been that of connectivity or interconnectedness. We can no longer draw firm boundaries between the global and the local, the national and international or the economic and cultural dimensions of contemporary life. We cannot separate the 'in here' of the city, community or locality in which we live from the 'out there' of global flows of money, capital, people, power and dominance. Thus globalisation is not an entity but a set of relationships. Our activities are all influenced by this complex and interrelated set of relationships that are 'stretching' social relations to an unprecedented degree. This is not a 'smooth' world where the overarching power differentials created by colonialism and imperialism are bound to disappear. Massive changes have occurred since the international division of labour emerging in the post-war period was at its height in the mid-1970s but old inequalities persist and new ones have been created.

The concept of 'time-space compression' proposed by David Harvey in the first wave of globalisation studies seemed to capture well the processes in course (Harvey 1989). Spatial barriers - for example in relation to trade and communications - have been considerably undermined, though this does not mean the 'end of geography' as the triumphalist globalizers of the 1990s declared. Time has also changed from being a reflection of a natural process (the day, the seasons) to being seen as instantaneous. We may not have reached the 'distanceless' world that Heidegger once foretold, but the 'shrinking' of the world greatly accelerated from the 1990s 
onwards. The qualities of time and space have been revolutionized and have changed the way we understand and represent the world. The elimination of spatial barriers and the compression of time do not, however, as we argue below, lead to a process of smooth and homogeneous social development. The changing spatiality of the global order is, if anything, more heterogeneous, differentiated and fragmented than it was in the past.

\subsection{The changing role of the nation-state}

With the end of the Cold War and the rise of the most recent phase of globalisation, many claimed that the Westphalian system of sovereign states was coming to an end. This included those who believed globalisation to be driven by the information revolution and held a more-orless optimistic view of the expansion of global interdependence and the notion that we all live in 'one world'. Some claimed that globalisation had caused the state to wither away which was often perceived as a positive development. Kenichi Ohmae (1995), for instance, argued that the globalisation of culture brought about by multimedia was key to undermining nationalism, which must be reduced (if not eliminated) in order to improve the quality of life of people globally. At the same time, he argued that the undermining of the nation-state was a positive development, as states were no longer the optimal geographical units for organizing economic activity, not least because of the rise of cross-border economic regions.

The 'globalisation skeptics' took a less enthusiastic approach to globalisation and maintained an emphasis on the nation-state, arguing that claims about the erosion of borders and the undermining of state power were overstated (Reis, 2004). Instead, it was argued that the state has continued to perform more or less the same functions that it had always performed and that there is nothing historically unprecedented about contemporary levels of economic interdependence. Some argued that though international economic conditions may work to constrain certain government actions, this does not mean that governments are immobilized. Rather, it was argued that the internationalisation of capital does not merely restrict policy 
choices, but it expands them as well (Weiss 1998: 385). Rather than focusing on global interconnectedness, skeptics further emphasized the heightened levels of internationalisation (or relations between nation-states) and the growing importance of regionalism, particularly in North America, the Asia-Pacific, and Europe.

While some were optimistic about the diffusion of authority attendant on the rise of globalization and the seeming decline of the nation-state critics such as Susan Strange (1996) argued that the changes associated with globalisation had limited the ability of states to exert influence over outcomes that matter most to people’s well-being. Instead, the deepening and expansion of market structures enhanced the power of private actors, which were increasingly acting as political authorities over a growing range of activities (1996: 45). As seen above, multinational corporations, for instance, have become more important sites of authority over labour-management relations, undermining the spatially-bounded authority of states. At the same time, the geography of taxation has been restructured as MNCs operating across multiple jurisdictions, along with wealthy individuals, have exploited 'offshore' tax regimes.

The early debates about globalisation also emphasized the changing nature of national security, which seemed to be moving away from a model based on the monopolisation of the use of force by the state toward a new global cooperative security community. This partly reflected changes taking place in the spatial control over movement, such as that which occurred with the introduction of the Schengen Area which eliminated border controls between 26 European countries. It also reflected the widening of the scope of security under globalisation, which increasingly came to include cross-border issues such as climate change.

A number of transformations taking place in the twenty-first century have shifted the context and the relevance of these debates dramatically. The geopolitics of state power has not been absorbed or subverted by economic globalization. Due primarily to a series of US interventions and miscalculations, virtually a whole region from Pakistan to Libya has become a 
seemingly permanent war zone with no peace in sight. A rivalry for influence between the US and Russia in the lands of the former Soviet Union has led to violent conflicts just short of allout war. The spectacular rise of China has also led to geopolitical tensions in the South China Sea, not to mention the possibility of a trade war with the US. Whereas the likes of Francis Fukuyama (1992) had proclaimed the 'end of history’, with liberal capitalist democracies emerging as the final form of human government, it is now clear that forms of political organisation have not been homogenised and globalisation did not usher in a linear move toward greater democratic openness.

Claims about the shrinking of geography through cultural homogenisation - i.e. through 'Americanisation' or 'McDonaldisation' - have not come to fruition and nationalist (often antiWestern) attitudes persist or )re-)emerge in many places. While certain dimensions of security continue to be addressed at the global level (namely with regard to climate change), regional security agreements such as the Schengen Agreement have been undermined by state responses to the influx of refugees from Syria and elsewhere, which have included the deployment of new migration controls, the erection of fences and walls, and even the use of direct violence. The election of Donald Trump as President of the US has thrown the future of the NATO military alliance into doubt while states such as Turkey have moved toward increasingly authoritarian rule.

The ways in which many states responded to the most recent global financial crisis is another signal of the continued relevance of state power and authority. The geographical expansion of finance, which David Harvey (2003) has described as a 'spatio-temporal fix' for the problems of profitability in the manufacturing sector, has brought with it recurring financial and economic crises. In the wake of the crisis of 2008, states in Europe and North America responded with massive (publicly funded) bail-outs, up to and including the full or partial nationalisation of banks, financial firms and other industries (such as the American automotive 
and British steel industries). While there is little evidence to suggest a dramatic re-regulation of global capital flows, there have been some moves toward greater oversight of finance and a number of countries in the Global North and South have introduced limited capital controls. At the same time, since the turn of the millennium, the BRICS states (Brazil, Russia, India, China, South Africa) have been engaged in renewed state-led developmentalist projects that do not sit easily with the market-led economics of the pro-market period and also, arguably, reflect a Polanyian counter-movement process.

We also see a renewed emphasis on the nation state in the political developments of 2016, and there is much talk of a 'globalisation backlash'. The cycle that began in 1989 of a triumphant opening of borders and deregulation seemed to be coming to a close, or so did at least its acceptance as the common sense of the era. The basic tenets of globalization were challenged first in the UK through Brexit and then in the US through the Trump victory. Trade deals were questioned and the possibility of protectionism was back on the agenda. The free movement of people was rejected by many. This did not necessarily presage a return to the 1930s as some commentators in the heat of the moment suggested but it did, at minimum, point to the end of the early phase of globalization in the sense that it no longer held economic, political and social hegemony. Fundamental pillars of the post 1989 order- the single market in Europe and the North American Free Trade Agreement (NAFTA) in North America- were now in question and fundamental building blocks for Globalisation 2.0- such as the Trans-Pacific Partnership (TPP) and the Trans-Atlantic Trade and Investment Parnership (TTIP)- looked increasingly unlikely to materialize.

\subsection{New spatialities of development}

In terms of the broader spatialities of development, the dominant post-war development theory -the modernisation approach- maintained that there was just one true path to development and that was to ‘catch up’ with the original industrializing countries. The 
economics of the free market, the politics of Western democracy and the forward looking actors of Western culture would take us all to modernity along a teleological path. By the 1960s an alternative, more nationalist perspective had emerged based around the dependency paradigm. It turned modernisation on its head in terms of advocating a de-linking from the global economy but it shared a methodological nationalism with modernisation theory even if its vision was of a socialist future. In the more radical versions of the dependency approach, the path of dependent countries pointed rather to the 'development of underdevelopment' - things could only become worse. This prospect was amply disproven by the rise of the original NICs (newly industrialising countries) in the 1970s and 1980s particularly in South East Asia. The NICs were beginning to look like truly ‘developing’ countries.

The 1990s were characterized by a new version of modernisation theory, the so-called Washington Consensus building on the neoliberal creed inaugurated by the Pinochet dictatorship in 1973 and gaining momentum under the Thatcher and Reagan governments in the UK and US. The 'discipline of the market' would create 'investor confidence' as the state was forced to reduce its direct interventions and reframe its regulatory role. The new watchwords were liberalisation, flexibilisation and privatisation, designed to increase the power of capital and atomize organized social networks. Discipline in the workplace was deemed to be crucial to business confidence and the historic post-war balance between capital and labour incomes was dramatically altered in favour of the first. However a series of increasingly severe financial crises in Mexico (1994), across East Asia (1995) and Russia (1998) showed that this model was not sustainable. It reached its nadir in 2001 when Argentina’s economy collapsed after religiously following the International Monetary Fund's precepts for over a decade. It was only a matter of time before a more systemic crisis would emerge.

The early years of the new millenniums also saw the rise of the association of BRIC, which account for nearly half of the world population, a third of the world's land surface, and a 
quarter of the global economic output. The rise of the BRIC has fundamentally altered the sociospatial dynamic of global development and calls into question the current model of global governance. In 2003 this emerging South-East bloc was in a position to question the World Trade Organisation's free trade model and led the walk-out by the Group of 21 'developing' countries. When the 2008-09 global crisis emerged from within the Northern economies this bloc was not brought down through financial disintegration, as had been the case in earlier financial crises. While there was massive capital flight, a partial degree of decoupling from the global financial system meant that there was little exposure to the toxic assets of the North Atlantic economic system. If the crisis was to lead to a rethinking of the Washington Consensus it was also to usher in a more polycentric world order.

We are now clearly at the cusp of the globalisation wave which began in the 1990s. Probably the next wave will not see the same leading players (North Atlantic plus Japan) as other countries, regions and cultures to the East and the South continue to contest the hegemonic order. The future is uncertain and contested; there will be no simple progress to a Western model of modernity (Munck 2016a). Reform measures may include debt-reduction for low-income countries, controls in short-term capital movements, reforms of the international financial institutions, the curbing of financial speculation and a greater emphasis on domestic demand-led growth. In theory these measures might contribute to encourage a Polanyian style countermoment to address the social and ecological harm done by the unregulated market.

\subsection{New geographical mobilities}

The recession of the mid-1970s was a major economic turning point, marking the end of the system of mass production in the old industrial countries. This had both social and spatial consequences. Migrant labour recruitment was replaced by capital outflows to new industrial areas in the Global South. These in turn precipitated large-scale flows of workers, for instance from South Asia to the Gulf oil countries, and somewhat later from less-developed parts of Asia 
to the new industrial tigers. Between the mid-1970s and the outbreak of the global financial crisis in 2008, a new global labour market based on neo-liberal ideas developed. The governments of the old industrial countries expected that the outsourcing of manufacturing and the move to a post-industrial economy would eliminate the need for labour immigration. The new emphasis in the USA, Canada, Australia and Western Europe was on facilitating the entry of highly-skilled personnel and entrepreneurs. By the early 21st century, new industrial countries like South Korea, Hong Kong, Singapore and even China were joining the global competition to attract skills.

International migration is today an integral part of the transformation that is reshaping societies and politics around the globe. In many cases migration takes place under favourable conditions and leads to positive outcomes, but where migration becomes an act of desperation driven by violence or poverty, it throws up substantial challenges for the migrants themselves, and for the populations of origin, transit and destination countries.

The old dichotomy between migrant-sending and migrant-receiving countries is being eroded (Castles et al 2014). Most countries experience both emigration and immigration, although one or the other often predominates. The USA, Canada, Australia, New Zealand, Argentina and Brazil are considered ‘classical countries of immigration'. Their current people are the result of population-building immigration - to the detriment of indigenous peoples. Today, migration continues in new forms, with an emphasis on meeting labour market demand. Virtually all of Northern and Western Europe became areas of labour immigration and subsequent settlement after 1945. Since the 1980s, Southern European states like Greece, Italy and Spain, formerly zones of emigration, have also become immigration areas, although in recent years emigration has been increasing in response to the global economic crisis. Today Central and Eastern European states are experiencing both emigration and immigration.

The Middle East and North Africa region is affected by complex population movements. 
Some countries, like Turkey, Jordan and Morocco, have been major sources of migrant labour, while Turkey is now also an immigration country. The Gulf Oil states experience large, officially temporary, inflows of workers. Iran has been a major receiving country for refugees from Afghanistan, along with Pakistan. In Africa, colonialism and European settlement led to the establishment of migrant labour systems for plantations and mines. Decolonisation since the 1950s has sustained old migratory patterns - such as the flow of mineworkers to South Africa and Maghrebis to France - and started new ones, such as movements to Kenya, Gabon, and Nigeria, as well as to Europe. Although economic migration predominates, Africa has more refugees and internally-displaced persons (IDPs) relative to population size than any other region of the world. Asia and Latin America have complex migratory patterns within their regions, as well as increasing flows to the rest of the world.

According to the United Nations Department of Economic and Social Affairs, the world total stock of international migrants (defined as people living outside their country of birth or citizenship) grew from about 100 million in 1960 to 153 million in 2000 and then to 244 million in 2015. This sounds a lot, but was just 3.3 per cent of the world's 7.4 billion plus people. The number of international migrants has grown only slightly more rapidly than overall global population since 1960 (UN Population Division, 2009; UNDESA, 2013). However, falling costs of travel and communications have rapidly increased non-migratory forms of mobility such as tourism, business trips and commuting.

Thus nearly 97 per cent of people live in their countries of birth, and internal migration is far greater than international migration. It is impossible to know exact numbers of internal migrants, although the UN Development Programme estimated some 740 million in 2009 (UNDP, 2009). Internal and international migration are closely linked. Both are often ruralurban movement, linked to processes of economic transformation, which erode rural livelihoods, leaving little choice but to migrate to rapidly growing cities in search of work. In the world's 
population giants where industrialisation is concentrated in specific regions (like China, India, Indonesia or Brazil) rural-urban migration is mainly internal; for smaller countries or those in which economic development is lacking, rural-urban migration often means moving across national borders.

Inequality is a major driver of migration, but often in conjunction with other factors that trigger the decision to embark on difficult and risky journeys, whether in the form of internal or international migration. In many cases, people decide to migrate because their existing livelihood has been destroyed or rendered unviable. For example, the 'Green Revolution' (Glaser ed, 1987) in less-'developed' countries has increased agricultural outputs, while requiring significant capital outlays and larger farms. The benefits of the higher productivity are accrued by large landowners and transnational agri-business, while small farmers and landless labourers often lose their livelihoods. Many move to burgeoning slums in emerging industrial cities. Manufacturing - often in the form of sub-contracting for transnationals - has expanded, but job growth in the formal sector is inadequate for the growing urban population, so that many rural-urban migrants have to eke out a living in the informal sector.

'Migration crises', like those currently impacting in Europe, occur when conditions in origin areas become so bad that flight is essential. This may be because of civil war and sustained violence (as in the case of Syria) or because of a mix of poverty, lack of employment opportunities, and human insecurity. It follows from this that emergency migration flows are generally 'mixed flows', which undermine the administrative distinctions made by governments and agencies like the United Nations High Commissioner for Refugees (UNHCR). Migrant’s motivations are complex: they have to leave their place of origin, but also hope to build better lives for themselves and their families in another place.

Many people are today asking the question whether 'migration crises' are merely a passing phenomenon or a 'new normal' not just for Europe but for the world as whole? We are 
now able to answer this question: if global inequalities in incomes and human security continue to grow as they have in recent years, then crisis-driven migrations are indeed likely to become more frequent and larger in scope, presenting considerable challenges to potential destination states.

Against the background of the preceding analysis of the current situation and the dominant social and spatial transformation, the following three sections will illustrate in exemplary form some of the key tensions in the present. The ways in which these tensions will be addressed in future action is crucial to determine the prospects for social progress and the risks of social regress.

\section{Democracy and Capitalism}

During the final decade of the twentieth century, expectations of democratisation and economic globalisation went hand in hand, raising hopes for reaching a fully democratic world in which all material needs would be satisfied and poverty overcome. To many observers it appeared as if the commitment to "human rights and democracy" would diffuse ever more widely, encountering ever less explicit opponents. Political institutions were transformed by apparently incessant "waves of democratisation”. After the end of authoritarian regimes in Southern Europe during the 1970s, similar processes had occurred in South East Asia; military dictatorships had been overcome in Latin America; the apartheid regime had crumbled in South Africa; and Soviet-style socialism had disappeared in Eastern Europe and in the states emerging from the fall of the Soviet Union.

But this was not to pass.

\subsection{The paradox of the present}

Given the strengths of the beliefs in liberal democracy and the free market and the power with which institutional changes inspired by those beliefs made an impact on societies in many 
regions of the globe, it seemed as if political and economic progress were both well defined and unstoppably on their way. However this situation was not to last. Economic progress was highly uneven. Economic growth was spectacular in parts of East Asia and somewhat later, during the first decade of the 21st century, also throughout much of Latin America. But the post-Soviet societies suffered considerably from the free-market "shock therapy", even with reductions in life expectancy in the former Soviet Union. "Structural adjustment policies” had similarly negative effects in African and Latin American countries. True, later economic growth in Latin America and in post-apartheid South Africa was accompanied by extended welfare policies and the rise of new middle classes. In other regions, however, it created increasing social inequality and worsening working conditions. Industrialisation in so-called "emerging economies” goes along with dangerously reduced environmental quality in urban regions and intensified exploitation of nature, in particular through resource extraction. Despite de-industrialisation in formerly so-called "advanced economies", such exploitation has increased the risks and dangers related with climate change. Furthermore, the whole period from the 1990s to the present was marked by financial crises, first regionally in several countries of Latin America and East Asia, in Russia and in Turkey, then more widely diffused from the finance centres of the globe, since 2008.

In political terms, the picture is similarly ambiguous. There can be no doubt that democratic institutions are today much more widespread than, say, in 1980. In many cases, newly introduced democratic procedures have by now been operational over extended periods. In some countries, in particular in Latin America and South Africa, driven by the impetus of social movements, democracy has been highly innovative in facing social and environmental challenges. At the same time, it has become obvious that "democratisation” is by far not a linear, evolutionary process. Attempts at “democracy promotion” from the outside have led to the destruction of state structures. The “Arab Spring” was successful in bringing down autocratic 
regimes but, with the exception of Tunisia, has failed in creating democratic institutions. State failure, in turn, has entailed increasing and uncontrollable violence in large regions of the globe and has provided territorial bases for groups to spread violence worldwide. Furthermore, even within procedurally functioning democracies the relation between citizens and political institutions has often become thin and weak. Many citizens have stopped believing that their participation can have an effect on policy outcomes. Key areas of decision-making, such as on monetary policy through central banks, have indeed been insulated against democratic deliberation. As a response, citizens either turn away from politics, such citizen disaffection becoming visible in declining participation in elections. Or they express their discontent by supporting political parties, mostly newly arising, that mainly express distrust in the existing institutions and the "political class".

For all those reasons, the diffuse optimism of the late twentieth century has waned. Then, the dominant view was that the existing obstacles to free political and economic action only had to be removed, and progress would emerge. Since then, however, many of those supposed obstacles have effectively been removed, but the outcome certainly was not the great progress that had been promised and expected. Even though there has been progress, there clearly has not only been progress. In some respects, there has clearly been regress, even regress that endangers much of earlier progress. Thus, we have today rather divided views about how to assess the political and economic transformations of the past few decades, and we live in great uncertainty with regard to the outlook for the future.

\subsection{A short look at the historical experience}

Why should expectations for social progress be connected with democracy, with capitalism and with a combination of the two in the first place? With regard to democracy, the answer to this question may seem to be self-evident for us today. But we tend to forget that the idea of democracy, forcefully proposed in the late eighteenth century, was largely rejected by the elites 
in Europe, North and South America because of the instability and unpredictability that were associated with it. Capitalism, in turn, is anyway better known for its critics than for its proponents. It is widely seen as carrying social inequality, exploitation and alienation with it. Thus, it may sometimes seem as if proponents of democracy reject capitalism and that proponents of capitalism reject democracy.

There clearly is a tension between democracy and capitalism that needs to be better understood. But to do so, we first need to reconstruct the strong and clear arguments for both democracy and capitalism that have historically been put forward. Ideas that closely tie the progress of humankind with the advance of democracy and capitalism arose in the seventeenth and eighteenth century, and they retain some of their relevance today.

The period from 1500 to 1800, which historians of Europe call the early modern times, was marked by events that shook all certainties about the moral and political order, most importantly the encounter between people who did not know about the other's existence, when Europeans set foot in America, and the intra-Christian religious wars after the Reformation. These events sparked a radical rethinking of the basis of human existence and of our ways of living together. The notion arose that individual human beings have inalienable rights and that any legitimate political order needs to emerge from the agreement between those rights-holders. By the late eighteenth century, this combination of natural rights and social contract was connected with a further assumption: when free human beings bring their knowledge and their reason into the processes of deliberation and decision-making, the outcome will be superior to decisions by autocrats or oligarchs. Thus, democracy was not merely the only legitimate regime, it was also functionally superior to all other political forms. The idea of democracy incarnated political progress.

At the end of the eighteenth century the future progress of humankind as a society was seen as based on free human beings able to communicate with each other on equal terms about 
their ways of living together and on trading with each other the products of their labour in a peaceful and mutually beneficial way. During the nineteenth century, these ideas remained on the horizon, to some extent even on the agenda. Freedom of commerce became part of the many new constitutions. Free-trade agreements were signed between some countries. Sometimes the nineteenth century is also described as the era of the gradual extension of suffrage, as the beginning of the age of democratisation.

But it is quite misleading to read the nineteenth century in the light of the expectations for progress raised during the preceding period. Capitalist progress occurred more through industrialisation than through market exchange. Class-divided societies emerged instead of market societies in which producers met each other on equal terms. Institutional political participation remained restricted to men and to tax-paying property owners for most of the century. Universal suffrage was introduced rarely earlier than the end of the First World War, and even then women remained excluded in countries such as France and Italy. The formal abolition of slavery happened as late as the second half of the nineteenth century in some societies such as the United States of America and Brazil. Furthermore, large parts of the world lived under European colonial domination or, if not, under conditions of economic dependence from the leading powers. Attempts of elites to catch up with the leading powers and to emulate their path of progress, such as they were undertaken in Japan, Russia and the Ottoman Empire, were not inspired by notions of democratic popular sovereignty and market exchange as developed in the eighteenth century. Rather, progress was more and more identified with the rationalisation and centralisation of state structures and with industrialisation that was either state-led or led by large capitalist companies, supported by a modern science more and more oriented towards industrial production. This was the image of progress that was widely advertised at World Fairs in the period around the turn of the century. 
By 1900 the socio-political constellation was marked by a 'persistence of the Old Regime' (Mayer 1985) in which domestic, colonial or settler oligarchies dominated the majority population, combined with the emergence of an industry-based economic order, marked by industrialisation in the North-Atlantic region increasingly supplied with raw materials and agricultural products from other parts of the world mostly benefitted the dominating groups. But resistance to political and economic exclusion had increased. At the end of the First World War, during which the elites had become dependent on the majority population for the military effort itself and for the continuity of production while many men were at war, rights to political participation and to workers' organisation were widely extended in many societies. In parallel, the existing capitalist mode of industrial expansion reached a threshold, to be overcome later through mass consumption.

The combination of extension of democracy and capitalist crisis led to an explosive situation. The fact that democracy had become more widespread, at least in the procedural sense of equal universal suffrage, meant that demands by the population could not as easily be ignored or oppressed as during earlier periods. Economic crises, in turn, meant decline in production, rise in unemployment and increasing public deficits and, thus, entailed that material demands could not easily be satisfied either. The tension between democracy and capitalism that arose spelt the breakdown of democracy in many of the countries where it existed and the rise of authoritarian and totalitarian regimes.

\subsection{Rethinking the relation between democracy and capitalism}

These experiences made it necessary to rethink the eighteenth-century ideas of perennial progress through the extension of democracy and capitalism. Facing the rise of industrial capitalism and the denial of democracy during the nineteenth century, emerging critical thinking had assumed that there was a basic contradiction between capitalism and democracy that could only be overcome by superseding capitalism. However, the experiences of industrial-economic 
growth during the late nineteenth and early twentieth centuries had suggested that capitalist organisation of production could lead to social progress in terms of an improvement in the satisfaction of material needs. Social movements divided between those who continued to aim at overcoming capitalism and those who strove for reorienting capitalism towards social needs by embedding it politically into democratic frameworks. By the end of the First World War, the Bolshevik revolution in Russia and the introduction of egalitarian-inclusive democracy in several countries marked the temporary success of linking economic and political progress. By the beginning of the Second World War, the breakdowns of democracy and the rise of Nazism and Stalinism marked their failure.

A significant conclusion from these experiences is that it is equally erroneous to think that democracy and capitalism are in basic harmony with each other as different expressions of human freedom and self-determination as it is to see them in basic and irreconcilable contradiction with each other. Rather, there is a fundamental tension them, a tension that can explode in catastrophic terms. But there is no determinism at work.

Critical thinking had described the expansionism of capitalism as a tendency towards commodification, towards turning all relations between human beings into relations mediated by commodities. Thus, a thinking directed towards identifying ways and means for preventing the tension between democracy and capitalism from exploding may usefully explore the appropriate limits of commodification. Economic theory, indeed, had held that self-regulating markets would generate optimum collective outcomes assuming that what is exchanged on markets are commodities. But the original arguments about "sweet commerce" and "wealth of nations" did not entail that every aspect of social life was suitable for commercialisation and commodification. Commodities are goods and services that are produced in view of being sold. Much of that which is being sold in the history and present of capitalism, however, has not been produced towards that end. Trying to understand "the rise and fall of market society", Karl 
Polanyi (1944) rightly underlined that labour, land and money are not produced to be sold. Thus, economic thought and economic policy are wrong in treating them as commodities like other goods that are indeed produced to be sold. As a consequence, a market economy needs to be consciously embedded into society, not disembedded from it, as much free-market thinking tended to hold.

Analyses of the experiences with industrial-economic development and with the breakdowns of democracy have often focused on the adequate relation between states and markets as modes of regulation in terms of their functional efficacy. However, the necessary embedding of markets into society is more than a matter of formal regulation. Thinking of the democratic embedding of markets means that the degree and form of commodification becomes a subject of collective self-determination, the outcome of which will vary both in the light of earlier experiences made and of the specific conditions in which a society finds itself (Casassas and Wagner 2016).

After the Second World War, the democratic capitalist nation-state was seen as the answer to the tension between democracy and capitalism. It would be democratic as the expression of the collective self-determination of a nation through equal universal suffrage. At the same time, it would moderate political passions by focusing on electoral competition between moderate parties and discouraging uncontrolled social movement activity. It would reap the benefits of the functional efficacy of a market economy. But it would do so by embedding the latter into the national framework through political regulation of external commerce, not least through the currency but also through import substitution policies, and through domestic demand management, often to be called Keynesianism. Furthermore, taxation would be used as a means for social redistribution, paying for the building of welfare states.

In this form, the democratic capitalist nation-state was regarded as the container of social progress, as a general achievement at which humankind had arrived through historical learning. 
While developed in the North, the framework was thought to be applicable worldwide through “modernisation and development”. Decolonisation was an expression of collective selfdetermination of nations. And those new nations would embark on state-led policies of economic development. Such modernisation was expected, over time, to close the gap between "First” and “Third World”. Functional requirements of industrial organisation, in turn, would lead to convergence between the "First" and the socialist "Second World".

\subsection{The current challenge: towards a democratic re-embedding of the economy}

The political consequences of current economic policy making regimes are a considerably limited reach of democratic decision-making: policies concerning taxation, industrial relations or working conditions enter directly into the global competition for capital and tend to be not pursued if they affect adversely the "business climate". Others such as those concerning welfare or education are dependent on state revenues, thus are indirectly but severely affected by restrictive fiscal policies. Governments dependent on electoral majorities normally tend to avoid policies that make domestic social inequality rise. That the latter happens across many - though not all - democratic societies across the world gives testimony to the self-limitation of the reach of democracy. The very notion of government by regulation spells a farewell to democratic selfunderstandings, though its full technocratic meaning is hidden behind new terms such as governance, "best practice”, legitimation through efficiency etc.

The combination of the extension of the reach of capitalist practices and the self-limitation of the reach of democratic practices is at the core of a key paradox of our time: while there have never been more societies in which politics is based on democratic procedures, the actual capacity for substantive collective self-determination is radically diminished compared to preceding periods of democratic practices. Given that the current capitalist economy that has been disembedded from democracy is more crisis-prone than the embedded one, such a situation is highly unstable. It is dysfunctional even for much capitalist enterprise, as the recurrent crises 
show; and it falls normatively far short from what is possible in terms of satisfaction of material needs, of social justice, and of collective autonomy.

Many democratic governments have succumbed to the notion that the pursuit of domestic social justice is no longer possible under conditions of global capitalist conditions. By now they are regularly - and increasingly - paying the price for such an attitude through citizen disaffection and populist protest votes. It is only a matter of time for this downward turn to let explicitly anti-democratic governments come to power in apparently consolidated democratic settings. Democracy is not sustainable under conditions in which the elected declare themselves incapable of pursuing the expressed policy choices of the electorate. This diagnosis, though, is so bleak only for parts of the current situation. Many new or re-emerging democracies have been built on resistance to undemocratic and oppressive regimes through social movements. They keep being marked by intense political participation. And in many of them, such as Brazil and South Africa for much of the last two decades, economic policies have successfully been pursued in conjunction with expansive social policies. Significant poverty reduction and some decrease in social inequality have been the effects (Wagner 2016). To maintain or foster the social cohesion of a society by connecting economic with social policy under democratic conditions can become an asset in the current global context, a step towards upward social competition replacing downward economic competition between societies.

In times of global extension of economic networks, furthermore, it also needs to be recalled that the normative argument for a commercial society, as mentioned above, was not a call for a capitalist economy based on wage-labour, even though this became the dominant historical trajectory for more than a century. Today, the Polanyian notion of "re-embedding” should not be seen as limited to providing a statist frame for capitalism, given that this historical measure of "self-defense of society" is precisely what has been destroyed or at least considerably weakened in the recent dis-embedding of the economy from the democratic 
capitalist nation-state. Across the globe, today, alternative forms of economic activity exist and proliferate, not least due to the dysfunctions of the capitalist economy. They include timehonoured forms such as co-operatives and associations, often now re-constituted to face global challenges; directly anti-capitalist forms such as factory recuperations, or formally illegal ones such as occupation of land and buildings; producer-consumer networks for local and ecological consumption; regional initiatives to practice and promote new understandings of economic development, such as buen vivir in the Andean countries. The new movement of "self-defense" against the ravages of capitalism would need to be built from the accumulated experiences of such economic reorganisation with a view to building a global economy oriented towards social justice and ecological sustainability. Such economy is likely to include wage-labour as one of its forms, but no longer as the dominant one.

We need a new understanding of democracy, going both beyond mere individual “consumer” choice every four or five years between pre-fabricated political options and beyond the notion of an electoral majority imposing its preferences on the entire society. Political progress would be the building of a participatory democracy in which citizen involvement is a permanent feature. Furthermore, such involvement needs going beyond the mere choice between proposals made by instrumentally support-seeking elites, be it through elections or referenda, but should include serious deliberation about the issues at stake, the elaboration of policy options, and the evaluation of the consequences of all available options. Without such an understanding of democracy, the democratic form risks to remain an instrument in the hands of elites rather than the tool for collective self-determination.

The path towards the domestic economic and political progress sketched above is often described as unviable because of the current global context. Nation-states, even those of a considerable size, so the argument goes, face the global economic and political conditions as an unavoidable constraint. Such reasoning obviously contains a grain of truth under current 
conditions of global connectedness. However, it is also self-defeating since it rules out from the start the possibility of changing the global context. One may even surmise that the argument that nothing can be done serves a purpose: it exonerates business and government elites from responsibility for the consequences of their actions and in-actions. And at the same time it helps justifying whatever actions they take by permitting to argue that this was the only possible action given the global constraints.

While the argument contains a grain of truth, it hides a larger un-truth. There are at least two significant ways in which domestic actors, even from within smaller polities, can influence the global context: through aiming at international co-ordination and agreement, and through exemplary action. Under current conditions, polities are highly interdependent and much less in control of the effects of domestic policy choices than in earlier periods. At the same time, current means of information and communication also permit processes of international communication with a view to identifying problems and co-ordinating ways of addressing problems. The current debate over climate change is a case of intended co-ordination, with yet uncertain success. One also has to note, though, that common problem definition can have adverse effects, namely when a problem is misidentified and the solutions ill-designed. But if accompanied by intense ongoing communication, monitoring and deliberation, international communication can mitigate the significance of the external constraint for national actors by building momentum for common policy innovation. Importantly, the persistent plurality of political actors on the globe, in contrast to a world government, can also facilitate policy innovation. It allows individual actors or groups of actors to elaborate exemplary forms of action when co-ordination and agreement cannot be achieved.

Over the past three decades, the intensification of global economic activity under conditions of disembedding from democracy may have a mixed overall record, but it has clearly had two radically negative effects of global significance: it has created new forms of misery due 
to deteriorating living and working conditions in, often urban, sites of high economic activity and due to neglect of the rural population. And due to the acceleration of emission of pollutants through industry, transport, resource extraction and large-scale agriculture, it has endangered the very inhabitability of the planet or at least large regions of it. Both these effects have begun to be addressed in global terms: through poverty reduction programmes; through widely publicized denunciation of slavery-like working and living conditions; and through the beginning of coordinated action to reduce climate-changing emissions. Such activity has been pursued by various actors, from social movements to international agencies and commissions. Such manifoldness is an asset, allowing exemplary action to emerge and to be propagated. What is largely missing, however, is an attempt to bring together the meaning of those actions towards the elaboration of a new understanding that would see economic development as necessarily embedded within global policy choices.

To achieve such global embeddedness requires an elaboration of the meaning of democracy at the global level. There are good reasons against the idea of a global state and against world government. On the one side, political communication and deliberation in a single global polity could only be extremely “thin”, to use Michael Walzer's (1994) metaphor, and devoid of substance and meaning. On the other side, plurality is a value in its own right, and the idea of a global majority overruling a global minority is not very appealing. Thus, democratic deliberation and decision-making has its appropriate place in political collectivities that have a history of close connectedness and have acquired forms of political communication that support collective decision-making.

\section{Production and reproduction}

The process of economic internationalisation of the last 25 years has generated an unprecedented expansion of the global labour force. Our focus here is on production and 
reproduction as inseparable elements in the transformation of society. Likewise, we need to conceive of transformation in the world of work in the global North and the global South as inextricably linked. We also need to bear in mind that the move towards disembedding the economy from social relations creates a counter-movement through which society reacts in different ways to this process.

Due to the inter-linked processes of globalisation and informationalisation, as well as the steady increase in the proportion of women in paid employment, we have seen a massive increase in the number of people working worldwide. Best estimates are that the global workforce stood at 1,7 billion in 1980 and that it had risen to 2,9 million in 2010 (not quite doubling in size) with a projected 3.5 billion workers for 2030. Despite all the current emphasis on financialisation, work clearly continues to be of central importance to the global economy. It is the increase in workers that is driving social transformation, as much as the exponential increase in the number of personal computers. This world of production cannot be separated from the work of social reproduction which often takes place within households and communities, though the state and the market also play a role. The dominant economic policies of the last 25 years have severely impacted on household reproduction with a decline in welfare support and the negative impact of deregulation and privatisation on low income families.

In the 1960s the international development critique focused on the failure of economic growth to generate stable employment, with the underlying assumption that secure employment/livelihoods was essential to human flourishing. There was also a strong belief that bringing women into the labour market would loosen the structures of male dominance. However, as larger and larger numbers of women across the world enter the labour market, the labour market is becoming increasingly precarious in the North and the prospects for social protection/labour regulations is becoming increasingly remote in the global South. A rise in the number of women entering the labour market has been accompanied by shifting labour market 
conditions that have rendered more and more jobs for all workers akin to the precarious and informal forms of work traditionally associated with women. Taken together these processes can be understood as the feminisation of labour. Yet, the rise of the female breadwinner has not been accompanied by renegotiations of the gender division of unpaid reproductive labour within the domestic domain. Unpaid reproductive labour within the home remains invisible and largely uncounted. So, what we have seen is internal and international migration of mainly women from rural areas and poorer regions whose work plugs the care deficits in both wealthy and middle class homes, which then has mixed effects for the children (and elderly) they leave behind. The 2008/09 crisis resulted in what could be called a triple crisis of 'food/fuel/finance' in some of the countries the global South which has a profound and lasting impact on production and reproduction.

\subsection{De-industrialisation and the 'new' economy}

As some tendenies are diverging across regions, let us first look in some more detail at the North and then at the South. Over the last 25 years there has been a dramatic transformation in the world of work in the global North or the developed world as some still call it. Economic internationalisation and the new information technologies acted to transform production and reproduction in complex ways. In broad terms the period form the mid 1970s to the mid 1990s saw a significant shift away from manufacturing, once the distinguishing mark of what were called the advance industrial societies. The steady decline of traditional manufacturing jobs (along with the agricultural sector) did not lead to a homogeneous post-industrial economic order or an informational society.

The social transformation of the world of production and reproduction was not unilinear with contradictory tendencies towards new 'high tech’ work on the one hand and deskilling/flexibilisation on the other hand. Women gained a greater role in the new economy but also the gender division of labour became more oppressive for women for the reasons noted 
above. In the study of the shifting patterns of production since the 1950s much emphasis has been laid on the new information and communication technologies and the whole notion of automation. It would be too simplistic to say that new technologies simply replace workers. Notions of a 'workless future' or the 'death of the working class' have not come to fruition. Technological change more often lead to greater output demand thus increased production and a greater demand for labour. There is not, on the other hand, much empirical support for the notion that new technologies lead inevitably to social progress. New technologies are, most seemly, transforming everyday life and the whole area of production / reproduction social relations.

The new technologies hugely accelerated globalisation and facilitated the emergence of the global supply chains. But there were also adverse effects such as the stagnation of median real incomes and the growth of long-term unemployment. That workers were the losers in this new global capitalism is shown by the historic shift in the share of the national income going to labour (rather than capital). In the countries of the Organisation for Economic Co-operation and Development (OECD) this share had been steadily rising between 1950 and 1975 but then dropped from 66\% in 1990 to 60\% in 2010 and is now well below 1950 levels, showing a decisive shift in bargaining power away from workers.

Contrary to the rosy views of a modernisation theory which sees a constant advance of social progress, the advanced societies are moving towards more precarious employment relations, once seen as the preserve of the developing world. This has been dubbed by 'Brazilianisation' of the West, as precarity, informalisation and marginality become the norm and disrupt the post war social settlement (Beck 2000). For some workers in the North this is now an anachronism as countries like Brazil industrialise as their own de-industrialize and lead to the decomposition of stable working class patterns of production and reproduction. The new norm in terms of social relations of production is now becoming insecurity, informality and precarity of employment. In particular, youth unemployment rates have shot upwards since the onset of 
the crisis and show no sign of abating. While we must always be wary of a unilinear analysis, because there are always counter-trends, we would conclude that the once settled compromise between capital and labour in the advanced industrial societies is no longer the dominant pattern or a status quo that can easily be reverted to.

In the aftermath of the Great Recession of 2008-09 what were the employment trends in the OECD? World trade slowed dramatically despite some temporary recoveries. We saw a steady increase of what we can call vulnerable employment (self-employed and family workers) which points towards working poverty which increased by 23 million between 2009 and 2012 . Recovery was patchy and there were many setbacks after the initial coordinated fiscal and military stimulus policies in much of the North. Growing public deficits and sovereign debt problems in country after country (especially in Europe) led to so-called austerity policies in a vain attempt to reassure the capital markets. The Northern economy was steadily reducing its capacity to create new jobs. By 2012, compared to 2009, there were 30 million fewer people in the labour market compared to pre-crisis trends and projections. The system seemed to be running out of steam and capitalism's historical ability to bounce back from crisis through new technological breakthrough seemed in question.

\subsection{Industrialisation in the South and the new international division of labour}

The perspective from the South, however, differs considerably. From the mid 1970s to the mid-1990s as the North de-industrialised so the global South industrialised at a gradually increasing rate. Of the nearly doubling of the global labour force between 1980 and 2010, the large majority were accounted for by the 'farm to factory' shift in the South. In China, we have seen the emergence of 120 million non-agricultural jobs since the turn of century, leading to a dynamic industrialisation process. In India, a substantial 67 million jobs were added in the industrial and service sectors over the same period. In China, as is well known, this resulted in an unprecedented wave of urbanisation and industrialisation. In India, nearly half of all the new 
non-agricultural jobs were in the low-skill construction sector rather than the higher -value added manufacturing end of the spectrum. Likewise, in Latin America it is mainly in Brazil where social transformation through industrialisation was effective. Several other countries in the region remain linked into an extractive (agro-mining) economic model.

Development - defined as economic growth and social progress - is the main driver of transformation in the global South which has led to a new international division of labour, predicted in the 1970's but only fully realised over the last decade or so. This shows that the North-South divide was not condemned to continue an industrial-agrarian divide. What industrialisation across vast swathes of the global South from the 1970s onwards did not produce, however, was a convergence of incomes. Put at its simplest, industrialisation does not, in and of itself, lead to development. Industrial convergence from the 1980s onwards - as the North de-industrialised and the South industrialised - did not lead to a narrowing of the long standing North-South divide. In terms of global social progress it is thus clearly essential to address inter-country inequalities as much as intra-country inequalities.

The overwhelming fact of production in the global South is that it occurs primarily in the informal sector and sees the continuation - and even exacerbation - of precarious work (Munck 2016b). The model of the informal sector was a 1970s category which took the formal employment patterns of the North as the norm. There was an implicit expectation that this sector would help absorb the growing mass of people thrown off the land or out of urban jobs through the modernisation process. The problem was an assumed dualism between formal and informal sectors when in fact they were perfectly complementary. In practice informalisation, and what we today call precarisation, continues to dominate and is a critical component of capitalist globalisation. The notion of upgrading this sector and promoting 'decent work' norms, while laudatory, continues to posit a past northern pattern (full employment and welfare state) against which to measure the present. Social progress in the global South may take other forms and we 
need to be open to non-North - centric solutions.

There was an initial perception that the Great Recession (2008-2009) did not impact as severely in the Global South as it did in the North, as briefly discussed above. This was mainly due to continued growth in the BRIC countries but by 2015 even China's counted economic vitality was called into question by a volatile stock market. Overall, we note that while in 1994, 39 percent of the developing world's workers lived in conditions of extreme poverty (defined as less than US \$ 1.25 per day) this proportion had dropped to 25 percent in 2004 and 13 percent in 2014 (World Bank 2015). While on the surface an impressive achievement in terms of social progress (although questions remain over the methodologies used and measurement in China particularly) the quality of jobs in the 'developing' countries leave a lot to be desired. The barriers to female labour force participation continue to be very high, gender pay gaps persist, and in many cases, employment has not come with supports for domestic labour, leading to a double or triple burden. Youth unemployment rates continue to rise. More than half the workers in the developing world (1.5 billion) continue in so-called vulnerable employment and welfare rights are patchy at best. While the development imperative has driven up the number of workers in paid work across the global South in terms of social progress we have a less than optimistic scenario.

\subsection{Global work and gender}

When debates emerged around the 'feminisation of labour' in the late 1980s, this drew attention to several interrelated shifts associated with the model of globalisation we commented in previous pages. This model compelled greater numbers of women to enter the labour force while at the same time rendering labour markets increasingly precarious. One of the many paradoxes of this process is that insofar as there has been some erosion of gender inequality in labour markets this has largely happened as the result of the convergence of men and women at the lower rungs of the labour market rather than through the integration of women into the 
protected 'inside'. This is evidenced, for instance, in the (slight) fall in the gender gap in labour force participation rates that has occurred over the past two decades and has as much to do with falling rates for men as it does with rising rates for women.

The 2008 global financial crisis has worsened what progress was being made toward reducing gender inequality in labour markets (Elson 2010). Several years after the crisis, it has become clear that while some of the initial impacts in the developed economies affected those industries dominated by men (such as the financial, manufacturing and construction sectors), the impacts then spread to other sectors around the world, including into the service sectors that are dominated by women (ILO 2010: 5-6). Evidence from past and present crises suggests that where women are concentrated in export manufacturing (e.g. in Latin America and Asia), female job losses will probably be greater than male job losses. Women are also disproportionately affected by job losses in the textile and tourism sectors (e.g. in many parts of Africa and East Asia, incl. China). In the OECD countries, cuts in public sector jobs have had a drastic effect on women's employment. In the EU, where women constitute on average $69.2 \%$ of public sector workers, job losses, wage reductions and pay freezes disproportionately affect women. Signaling a reversal of progress that had been made in women's position in the labour market, female employment rates in 2012 had fallen below or close to the 2005 level in 22 EU Member States. The gender pay gap also increased in 9 Member States (European Women's Lobby 2012).

Despite these recent shifts, women have participated in large numbers in the massive increase in the global workforce since the 1980s. Yet, they have often gained jobs in contexts where male employment was either stagnant or declining. Women's growing share of the workforce, its so-called 'feminisation', has attracted a great deal of attention in the literature because of the view that the entry of women into the workforce would release them from patriarchal constraints within the home and lead to their emancipation. However, these theories flourished in an era when employment was associated with stable, full-time jobs in large-scale 
factory production systems that allowed workers to unionize to defend their rights. These are the jobs that the International Labour Organisation (ILO) continues to describe as 'typical'. Yet a sizeable majority of women today are to be found in jobs that are considered 'atypical' and whose emancipatory potential has become the subject of a great deal of debate.

There are various forces behind the rise of female labour force participation rates across the world. Falling fertility rates, rising levels of female education and changing aspirations have made it both possible and desirable for women to take up paid work. Women have also been 'pushed' into the labour market by the declining importance of agriculture, growing landlessness, urbanisation, economic recession, debt crisis, structural adjustment policies and accompanying declines in male employment prospects and wages.

In addition, we witness the changing nature of the global economy and the emergence of a female-specific demand for labour. The ascendancy of neo-liberal ideologies across the world has made the pursuit of market-led growth the central driving force in shaping the pace and pattern of globalisation, putting pressure on all countries to hone their international competitiveness through the deregulation of labour markets. Women have emerged as the flexible labour force par excellence within this new global regime: they are generally free of the 'fixed costs' associated with organised labour; their continued responsibility for unpaid care work within the home combined with the gender-stratified occupational structure serve to curtail their options and weaken their bargaining power while hegemonic ideologies of the male breadwinner are used to justify paying them less than men.

Women have therefore increased their share of the labour market at a time when labour markets are increasingly deregulated and when jobs have become increasingly 'atypical' for both men and women. At the same time, they continue to predominate in the lower ranks of the occupational hierarchy with more limited job opportunities than men and lower earnings. Within the OECD context, the gender wage gap has declined but women's continued responsibility for 
unpaid care and domestic work within the home means they are more likely to be in low-paid, flexible and part-time work than men, with working mothers suffering an additional 'motherhood penalty'.

Elsewhere, globalisation has contributed to women's labour force participation through two primary routes: the generation of jobs associated with the trade in commodities and of jobs associated with the movement of labour. The generation of jobs through increased trade in commodities has taken a number of forms. In some cases, technological change combined with the search for flexible labour arrangements in an increasingly competitive global environment has led multinational firms to locate different stages of labour-intensive manufacturing (garments, textiles, electronics) and services (call centres, back office processing) to different parts of the world in order to take advantage of differences in wage costs, factor endowments or congenial investment climates. In other cases, countries seeking to earn foreign exchange have sought to exploit their location-specific comparative advantage to expand trade in tourism as well traditional (coffee, cocoa, bananas) and non-traditional (flowers, fruits, organic crops) agricultural commodities.

\subsection{Global value chains and the gender division of labour}

The concept of global value chains was developed to map the distribution of roles, activities and value-addition of goods and services whose production, distribution and consumption cut across national boundaries. Global value chains in labour-intensive manufacture of consumer goods, services and non-traditional agricultural exports tend to be driven by large retailers, branded manufacturers and supermarkets who draw their profits from high-value research, design, sales and marketing stages which are characterised by high barriers to entry. The production end of these global chains, on the other hand, is characterised by low barriers to entry and decentralized production networks, made up of highly competitive workshops, farms and factories, generally located in the informal economies of low-wage 
countries. This is where most women workers producing for global markets are located.

The conditions in which they work vary considerably, depending on whether they are employed by multinationals or their direct suppliers or whether they are subcontracted based upon smaller workshop or home-based piece work. By and large, wages and working conditions are better, the more direct the relationship between multinationals and workers and not simply due to the higher levels of profit that characterise these organisations. It also reflects the pressure that has been brought to bear on these organisations. The nature of the linkages within these global value chains has allowed transnational activists to mobilize consumer support in affluent countries to force multinationals to adopt corporate codes of conduct to ensure minimum labour standards are observed.

There are however clear limits to what has been achieved - both in terms of the standards observed and of which suppliers are included. In particular, the right to association and collective bargaining remains one of the least enforced clauses of these codes of conduct and generally enforcement does not go beyond direct suppliers. These are sectors characterised by highly mobile capital and the constant threat of relocation serves to curtail the capacity of workers to mobilize for enforcement.

The other route through which globalisation has generated jobs for women has been through the growing cross-border movements in search of jobs. By 2006, women represented almost half of the total number of international migrants, with many now migrating on their own rather than with other family members. They migrate because of lack of opportunities or social restrictions on their life choices in their own countries, as well as their awareness of opportunities in more affluent countries.

A significant proportion of these opportunities have been generated by the movement of women into paid work in affluent regions of the world. In the absence of much change in the gender division of unpaid care work and household chores, there is a growing demand for paid 
domestic workers by those women who can afford it. The availability of migrant labour provides a pool of low-cost labour to meet this demand. Restrictions on the mobility of labour, in stark contrast to the almost unfettered mobility of capital, has meant that legal migration is generally based on temporary contracts with fewer rights than other workers and little opportunity to engage in collective action to improve the terms of employment. At an even greater disadvantage are those who enter without documentation and have hardly any rights at all.

Contrary therefore to the more optimistic expectations, women's greater entry into the labour market has not been accompanied by their widespread emancipation. Some women have made it into the higher levels of management in some countries but most women continue to be concentrated in forms of work that do not hold out much transformative potential: part-time, low paid work in the Global North and temporary, irregular and informal employment in the Global South.

\subsection{Global care chains and migration}

Changes associated with the global feminisation of labour have meant that women's paid labour has become increasingly important to the survival of families and communities. This has helped to fuel women's labour migration, particularly in the areas of domestic and/or care work.

Migration may be from rural to urban areas, or from poorer to (relatively) richer countries. In both cases, the remittances sent home to families has become an important source of income.

In many advanced industrialized countries, demand for this work has been fuelled by women's entry into the paid labour force not matched by a shift in the gender-based division of unpaid labour in the home or in state support for childcare. However, it has also been prompted by shifting demographics. The Japanese Ministry of Health, Labour and Wealth, for instance, projected that the country, which employed 1.77 million care workers in 2013, would need 2.53 million care workers in 2025 (Onuki, forthcoming).

The demand for female domestic workers has also grown in middle-income and 
‘developing’ countries. In Asia, for instance, wealthier countries such as South Korea, Japan, Malaysia and Taiwan have attracted large numbers of migrants from poorer countries in the region (Seol and Skinny 2009). In many cases, bilateral labour agreements are designed in ways that support short-term (i.e. temporary) migration of sole workers, forcing them to leave families behind. These agreements also tend to make it difficult for workers to report violations of their working conditions or abuse from their employers, as visa status is often tied to employment with a particular employer. While domestic work may present the best option for women in poor countries and regions, the work is often low paid and highly exploitative, with nannies expected to work evening and weekends and to be on call at all times. It has also been found that in certain regions, domestic work relies on child labour. According to the ILO, approximately. 175,000 children under 18 are employed in domestic service in Central America and more than 688,000 in Indonesia.

These "global care chains” (Hochschild 2000) further increase the amount of domestic work that is left to be done by those (mainly women) who care for the families left behind. As with much reproductive work, this work has been hidden and privatized. So too has the work done by those mothers that migrate, who engage in the paid work of social reproduction while simultaneously performing motherhood for their own children at a distance - what has been called “transnational motherhood” (Arat-Koç 2006).

Transnationalized relations of social reproduction also incorporate other dimensions of migration. For example, mothers may move to care for their children who have been sent abroad to receive education in places like Korea or Taiwan (Kofman 2012: 10; Chee 2003). Migrant domestic workers form a category of gendered and racialized labour that has expanded remarkably in virtually all advanced industrial economies (Anderson 2000; and 2007; Cox 2006). Domestic and care work is marked by hierarchies of work tasks, of formal and informal modes of employment, and of groups with varied statuses (Huang, Thang and Toyota 2012). For 
instance, Filipina domestic workers are preferred in some places due to their better education and English, but rejected in others because they are seen as too active in defending their rights. Domestic work by migrant women can be the result of increased opportunities of professional or white-collar employment for majority-group women: hiring foreign maids can free women in Italy, the USA or Singapore from housework and childcare (Iredale, Guo and Rozario 2002; Huang, Yeoh and Rahman 2005). Such transnational care hierarchies sometimes go a stage further, when migrant domestic workers hire a maid in the home country to look after their own children. 'Global care chains’ may mean higher living standards and better education, but at a high emotional cost (Yeates 2012).

\subsection{Global social policy}

Among the global social policy proposals on the table to deal with the global financial crisis on the realms of production and reproduction one of the potentially most far reaching is the Social Protection Floor Initiative, led by the ILO and the World Health Organisation. It sets out two broad elements to secure basic social services for the most needy: 1) A basic set of essential social rights and transfers, in cash and in kind, to provide a minimum income and livelihood security for all and to facilitate effective demand for and access to essential goods and services and 2) The supply of an essential level of goods and social services such as health, water and sanitation, education, food, housing, life and asset-saving information that are accessible for all. There is clearly an urgent need for such a coordinated international effort to secure basic social protection for all now struggling to survive in the poorest countries. But we must note that in and of itself the social protection floor will not alter the architecture of a global political economy that produces extreme poverty and inequality even while it generates untold wealth and privilege for the few. 


\section{Demographic change, consumption and sustainability}

The sustainability of the human way of life on our planet has been a rising concern for at least half a century. It was first raised with regard to the depletion of resources, then widened into a general ecological concern about risks for health and biological diversity, and reached its height

with imminent climate change endangering living conditions in major parts of the world. The consequences of human interventions into the biology and geology of the earth have reached such dimensions that geologists started to speak of a new era, the anthropocene, beginning at around 1800 , as the era in which the main determinant of planetary changes is the human being.

Such impact results from various elements: the number of human beings living on the earth; their material way of life; and the kind of technology they use. An early attempt, at the beginning of this concern, to disaggregate different drivers of environmental impact was made in the 'IPAT equation’ of Ehrlich and Holden (1971). This identity states that environmental impact (I) is the product of population (P), the level of affluence (A), usually measured by GDP per capita, and the level of technology (T), measured by the impact per unit of GDP, so that $\mathrm{I}=\mathrm{P} \times \mathrm{A} \times \mathrm{T}$.

So, for example, $\mathrm{CO}_{2}$ emissions are the product of population, GDP per capita and $\mathrm{CO}_{2}$ emissions per unit of GDP. Though these factors are not independent, decomposing impacts in this way highlights the relative contribution of the different drivers. For global environmental impacts such as $\mathrm{CO}_{2}$ emissions, though technological improvements and changes within sociotechnical systems have led to reductions in T, i.e. lower impacts per unit of economic activity, this has been more than offset by growth in P and A, population and GDP per capita. Or in other words, a larger population and greater material affluence have increased environmental impact; they would continue to do so unless technological changes and changes in the way of life work to reduce such impact. In the following, we explore this tension in the current situation by looking first at the trends of population growth. 


\subsection{Population growth and consumption}

Population growth is crucial when dealing with sustainable development. The wave of growth of the population of the world, initiated more than two centuries ago, is slowly on the waning. The speed of growth was just 3 per thousand per year during the eighteenth century, 5 per thousand during the nineteenth, 9 per thousand in the first half of the twentieth, peaking at 18 per thousand in the second half. Reliable current evaluations set the present rate of growth at 11 per thousand, and there is a widespread consensus among the experts that the decline will continue, approximating zero growth by the beginning of next century. Recent UN projections set the world population at about 11 billion people by the year 2100, a tenfold increase since 1800, and the double of the size reached at the end of the $20^{\text {th }}$ century (UN 2015b). Oversimplifying a very complex history, this cycle is the result of the modern demographic revolution, due to the historical transition from high to low patterns of mortality and fertility; a revolution that in the rich countries in Europe and North America initiated in the first part of the nineteenth century and saw its conclusion at mid-twentieth century. The same revolution begun more than a century later in the rest of the world and has still to run its full course.

The general mechanisms of the modern demographic revolution, or transition, are well understood: broadly speaking, they are the consequence of the rupture of the syndrome of poverty, both of resources and of knowledge, that have kept mortality at a very high level since the beginning of mankind. The rupture of the syndrome has increased survival and the expectation of life and, subsequently, with a gap of a few decades, brought about a gradual adjustment of fertility. The fall of the death rate has generally preceded that of the birth rate causing an acceleration of population growth that, subsequently, has slowed down with the fall of the birth rate. With modernity, survival and reproduction cease to be conditioned by instinct, biology, and material constraints and are, more and more, the fruit of individual choice and behavior. 
The relative inertia typical of population change makes a projection over a generation relatively reliable, at least at the world and regional level. Let us therefore consider the possible trends over the 2015-2050 period: according to the UN projections, world population will increase from 7.3 to 9.7 billion, or 2.4 billion over 35 years (the same number was added to the world population in the 29 years between 1986 and 2015, and in the 36 years between 1950 and 1986). In other words, there will be 2.4 billion more people on the earth to be fed, clothed, and housed; they will need energy and combustibles for heating, cooking, and transportation; they will need working tools, infrastructures, manufactured goods made with raw materials and energy; they will use and consume space. The economic system must be able to cope with this additional aggregate demand, while the environment will undergo an accrued human impact. Almost $50 \%$ of the world population increase will take place in Africa and an additional $28 \%$ in the Indian subcontinent. In Europe, China and Japan, population will initiate a declining course well before mid-century; urban population will continue to grow, while the rural population will continue to decline. Although comprehensive projections are missing, it can be confidently said that the population of the coastal areas - more fragile and more densely populated - will continue their fast growth, much faster than the areas of the interior. Finally there are concerns that the general population growth will accelerate the intrusion in other fragile areas, such as the pluvial forests.

The population question, central to the debate on development in the second part of last century, is slowly sliding out of the international agenda. In the background of the population conferences promoted by the United Nations in 1974, 1984 and 1994 stood the issue of the unsustainability of the rapid world population growth, particularly in what used to be called the less 'developed' countries. Not least for diplomatic reasons, this central concern was not explicitly put on the table, but emerged in the discussions and in the documents whenever they dealt with the various aspects of population change. Population issues were still present in the 
solemn UN Millennium Declaration of the year 2000 and were addressed by some of the Millennium Development Goals (MDGs), but have almost disappeared from the debates leading to the approval, by the UN General Assembly, of the 2030 Agenda and of the Sustainable Development Goals (SDGs) for 2015-2030. Population growth is indeed slowing its pace, but this fact should not push into oblivion several major developments, of a demographic nature, that threaten the "sustainability" notion that informs the 2030 Agenda. Among these are the very rapid growth of the African continent, the very low fertility of eastern Asia and of Europe, the international migration flows, the unchecked human penetration in fragile or pristine areas, or the fact that population growth can be a major factor of global warming.

Given the moderate levels of mortality prevailing in a large majority of countries, the main driver of population growth is fertility that, at the global level, has undergone a sustained decline. Sixty years ago, the number of children per woman for the entire world was around 5, reduced by half to 2,5 in 2010-15. But given the unequal pace and timing of the demographic transition in the various areas of the world, there are, nowadays, populations with persistently high fertility, and populations where fertility remains well below replacement. In Sub-Saharan Africa the number of children per woman stands at 5.1 (2010-15), more than triple the levels of China and Europe (1.5-1.6). If fertility of Sub-Saharan Africa remained unchanged (in Nigeria, the most populous country of Africa, fertility is close to 6), its population would treble by 2050, from 0.96 to 2,75 billion in 35 years. These numbers would require an extraordinary rate of economic growth in order to allow for sufficient investments in infrastructures, raise out of extreme poverty hundreds of million people, eradicate hunger, improve the modest levels of consumption of the rest of the population. The environmental impact of these growing numbers of people, with an increased per capita income, would be very high, if their ways of life followed the patterns set by Western Europe and North America earlier. If nothing else changed, this 
rapid population growth would threaten - if not make impossible - the viability of the sustainability paradigm in the region.

The transition from high to moderate fertility is linked to well known developments, beside a general improvement of the economic conditions of the population. Chiefly among these are the improvement of health and a sustained decline of child mortality; primary education for all; empowerment of women over a wide range of issues; the end of gender discrimination. More specifically, given the high proportion of women with unmet needs of contraception (globally, almost 1 in 5), at the core of policies should remain the provision of a full range of safe, reliable and good quality contraceptive services. For the countries where fertility is very low, there is a (tepid) consensus that current low levels will give way to a gradual recovery: this is the position of the institutions and researchers who venture demographic forecasts and projections. Why this should happen is not clear: some argue that since very low fertility generates negative economic externalities, states may react by channeling more resources to couples and families, inducing them to have more children. The problem is, however, how to solve the conflict between the negative externalities produced by low fertility and the economic benefits - for the parents - of having one child instead of two, or two instead of three.

A further threat to sustainability comes from the growing environmental impact of income growth, again for the moment assuming technology and way of life according to unchanged Northwestern models. Let's take the cases of Europe and Sub-Saharan Africa: while in the former region population will be almost stationary over the 2015-2050 period, in the latter the rate of growth will be approximately $2 \%$ per year. Let us further make the hypothesis that per capita income will grow, in the two areas, at the respective rates of $2 \%$ (a rather optimistic hypothesis for Europe) and 5\% (a plausible pace in Sub-Saharan Africa for many economists). Since, without change in technology and way of life, the physical impact of mankind on Earth is 
a function of the combination of population and economic affluence (or income or product), the simple multiplicative algorithm, as introduced above, tells us that, over the next 35 years, such impact (assuming business as usual) would double in Europe and increase more than twelvefold in Sub-Saharan Africa.

There are other areas of the world, beside Africa, where fertility and the rate of growth are very high, taking account also of the density, distribution patterns of settlement, conformation of the land and other environmental characteristics. Population growth is also a powerful factor in the process of global warming; a determinant of the pressure on fragile or pristine territories; a determinant of human intrusion into vital areas such as pluvial forests and inland water reserves. For all those reasons, population growth must remain a central element in the debate on sustainability.

\subsection{Sustainability}

However, the issue of population growth needs to be seen within the wider challenge of achieving a sustainability transition that enhances human wellbeing for all, whilst ensuring that the impacts of human activity remain within planetary boundaries. We all know that technology may decouple economic growth from unsustainable patterns of production and consumption. In other words, with different technology it is possible to lower the content of energy and nonrenewable materials of every additional unit produced or consumed. Furthermore, changes in way of life - such as settlement patterns, intensity of transportation - may reduce resource use even with given technology.

In the 1970s, debates on sustainable development tended to focus on the challenges associated with population growth. Whilst population is often not headlined for political sensitivity reasons, several measures enshrined in the 2015 Sustainable Development Goals for 2030 will lead to reductions in fertility in poorer countries, including reducing child and maternal mortality, access to pre-primary and primary education for all, and universal access to 
sexual and reproductive health and reproductive rights. But in recent years, furthermore, debates on sustainable development have increasingly centred on the question of the compatibility or otherwise of current levels of affluence and consumption with the need to reduce environment impacts so as to remain within planetary boundaries, including those relating to climate change, biodiversity loss and nutrient cycling (Steffen et al. 2015). Two broad approaches have been proposed.

The more radical view argues that the previous positive relation between levels of GDP and measures of human wellbeing has broken down since the 1970s, so that continuing high rates of economic growth are no longer delivering improvements in human wellbeing in richer countries, even when these growth rates can be achieved. Combined with the need to reduce environmental impacts to within planetary boundaries, those who take this view argue that richer countries should pursue a strategy of ‘prosperity without growth’ (Jackson 2009). Whilst this position is sometimes caricatured as proposing a zero level of GDP growth, more thoughtful proponents of this view argue that only a radical reconfiguration of current economic systems would be able to reconcile human wellbeing and environmental goals.

The more mainstream view, often characterised as green growth, argues that continuing high levels of GDP growth are in fact necessary to enable the high levels of investment needed in research and development and deployment of new technologies with much lower carbon emissions and other environmental impacts. In this way, growth in resource use and material consumption would be constrained to remain within environmental limits, whilst economic growth would continue, increasingly powered by activities within the ‘intellectual economy’ (Bowen and Hepburn 2013). This would lead to an 'absolute decoupling' of economic growth and environmental impact, as reduction in the T factor in the IPAT equation would offset continuing growth in affluence and population, until a stable population is reached. 
Debates between these two views centre on the aspirations of the new citizens growing up in extreme poverty in 'developing' countries, as well as the political tractability of economic system change. Proponents of the more radical view argue that most citizens of 'developing' countries aspire to the lifestyles of those in richer countries, as communicated globally through the internet and images from television and Hollywood movies. If this aspiration were to be achieved at current average levels of per capita consumption in richer countries, then this would lead to levels of resource use and environmental impact far exceeding global environmental limits. Under this view, the unprecedented levels of technological change needed to reduce impacts per unit of GDP are highly unlikely to be achieved under the current economic system which prioritises increasing consumption as the primary route to human wellbeing. Instead, they argue for a strategy of reducing wasteful levels of consumption in richer countries, whilst strengthening community-based routes to wellbeing, and focussing on more decentralised, resource efficient and locally owned technology solutions for 'developing’ countries.

Proponents of the more mainstream view argue that any constraints on economic growth in richer countries would undermine the opportunities for development to meet the aspirations of citizens in 'developing' countries, as well as constraining investment in more resource efficient technological solutions and being politically untractable in richer countries. Instead, they argue for much greater emphasis on improving and deploying new technologies in both richer and 'developing' countries that would reduce global environment impacts, such as $\mathrm{CO}_{2}$ emissions, whilst bringing local health, air quality and economic benefits. Nevertheless, they recognise that even such a focus on green growth would require a significant reorientation of current political and economic priorities.

Whichever of these views, or more subtle new ideas, prevails in these debates on sustainable development, it is clear that achieving legitimate aspirations of those in 'developing' countries for a better life, enacting measures to constrain fertility rates consistent with individual 
liberties and human rights, addressing current high levels of global inequality, and ensuring that the impacts of human activity remain within planetary boundaries are central to realising social progress towards a better society.

\subsection{Mobility}

Mobility - domestic and international - is a structural capability of humans and a vital component of human capital, and is a powerful factor of social progress. But the absence of an even moderate global governance of international migration is a major threat to the political and social sustainability of social development. Among the SDGs (and targets) of the UN 2030 Agenda, there is almost no mention of international migration, except a reference (target 10.7, the only one on migration out of a total of 69 targets) to the need to "facilitate orderly, safe, regular and responsible migration and mobility of people...”, generic and ambiguous (who is going to facilitate? What does "responsible migration” mean?) and impossible to achieve without an embryo of international governance of flows. This summarizes the profoundly rooted unwillingness of states to deal with the issue, and to entrust even a small fraction of their sovereignty to an international institution in order to regulate international flows. There are strong forces generating global migration flows, because of the growing planetary interconnection between economies and cultures, the "shrinking" of the world and, most of all, because of the still profound economic and demographic divide between rich and poor countries.

\section{Actors for Social Progress}

Social progress is full of ambiguities. The ways in which social progress has been produced in the past also puts further progress at risk. Among the problems discussed in the previous sections that need to be resolved are the following:

- $\quad$ Climate change and the deterioration of the human environment.

- $\quad$ The fragmentation, down-grading, and exclusion of labour. 
- Racial, gender and religious discrimination.

- Increasing economic, social, and health inequality.

- Regional disparities and shifting geographical divisions of labour.

- Fundamental tensions between capitalism, democracy and human rights.

- Environmental consequences of economic growth and increasing population densities.

These obstacles are often interconnected; frequently, one issue cannot be solved without solving others. To bring back social progress calls for a new Great Transformation which would re-embed market forces into society and nature. This time round the re-embedding cannot just be accomplished through national government intervention, but needs new constellations of actors and new forms of conscious action as a pre-condition for re-generating expectations for social progress, but in the end its realisation will depend on the emergence of a new governance model which relies less on the nation-state, and more on non-state actors, international institutions and local action. To finish this opening chapter we provide a brief cross-section of collective action which is central to bring about the next Great Transformation.

\subsection{Protest on the rise}

Dissatisfaction with injustices and inequities is widespread. During the last decade protests have grown in all regions of the world. Several research reports confirm, that "despite the absence of exactitude in measurement, data from the past several decades do point to a fairly clear pattern of increasing frequency. Major protests multiplied in the second half of the 1980s and early 1990s, coinciding with what is commonly called the third wave of democracy, but then decreased significantly throughout the 1990s and the first half of the 2000s. Protests began to accelerate again in the second half of the 2000s and have reached a peak in the past five years [i.e. 2011-15].” (Carrothers/Youngs 2015; see also Ortiz et al., 2013, and Economist Intelligence Unit, 2013)

The large majority of protest events address their grievances to their own national 
governments, and demand that these governments develop economic, social and environmental policies that are in the interest of the population at large, and not of only the wealthy and powerful. Social movement organizations are numerous and very heterogeneous, varying from the Occupy initiatives and the World Social Fora, via Via Campesina, the Zapatistas, the Brazilian Movimento dos Trabalhadores Sem Terra (MST), and the Argentinian Piqueteros, to the Self-Employed Women's Association and the New Trade Union Initiative in India. The demands put forward by protesters are generally sundry, and the forms protests take are heterogeneous. Protests oppose the elimination of subsidies on food and fuel; wage cuts; VAT increases on basic goods and services; the emaciation of social security; the reform of pension and health care systems; the flexibilisation of labour; but also pollution, war, rape and corporate influence. The lack of "real democracy" is a regular issue.

Naturally, social movements and social contestations do not fight for "social progress" as such, but focus on more specific issues. Their activities are not only numerous, but also extremely heterogeneous. Worldwide there are hundreds of thousands of unions, associations and groups defending the interests of the disadvantaged and those discriminated against: workers, women, people of colour, LGBTQ, etc. The number of environmentalist groups is impressive too, as are the initiatives against organized violence in its multiple shapes. In addition, the awareness has increased that lasting change for the better can no longer be realized only on a national scale. The number of transnationally organized social-movement organisations (TSMOs) has grown dramatically since the 1970s, from 183 in 1973, to 348 in 1983, 711 in 1993 and over a thousand in 2003 (Smith 2005: 266). The number of nongovernmental organisations is even vastly larger, while the number of international NGOs (INGOs) has in recent decades increased significantly as well.

There are huge tensions between these many institutional actors. INGOs and NGOs are mostly advocacy organisations without a proper membership structure, defending the interests of 
people, animals or natural riches that are supposed not to "speak for themselves". They often compete with emancipatory movements of subaltern groups and minorities, and sometimes weaken these movements by recruiting talented leaders for their own purposes (Petras 1999). More importantly, the many actors in the field have notorious substantive differences, and sometimes work in opposing directions. NGOs and interest groups frequently focus on issues that may be mutually conflicting, e.g. environmental interests and labour interests. Even within separate movements incompatibilities may occur, for instance between workers in rich and poor countries. The majority of the TSMOs organize around issues of human rights, although especially in the low-income countries they often engage with multiple issues. And finally, the arrival of a new wave of globalisation and its concurrent ideology of 'free markets' has simultaneously weakened some actors, while it has strengthened others.

We live in a transitional period in which many challenges can no longer be dealt with by national authorities, and not yet (if ever) by supranational or world authorities. "In the contemporary global world, there is no equivalent of the nation state at the world level that could implement fiscal and welfare policies, anti-trust controls, labor and environmental laws aimed at regulating markets and at correcting market failures. Nor is there a world independent judiciary which can control and sanction illegal behavior. Nor is there a democratic polity at the world level [...].” (Martinelli 2005: 247) This helps to explain the "negative” attitude of many social movements that say "no" to certain developments and have no positive alternative, because this would require a world authority. Nevertheless, transnational action focused on states is even possible under these adverse circumstances - either by pressing national governments to coordinate policies across borders, or by exemplary local activities that can inspire movements in other parts of the world (Ferrara 2008).

\subsection{Movements in decline}

A comparison between some declining and rising social movements can illustrate uneven 
development. National liberation movements have been extremely important during a large part of the twentieth century, but have currently lost much of their impetus.

Labour movements are the 'classical' social movements, but they have been severely enfeebled as well by the political and economic changes of the last fourty years. Their core consists of three forms of social movement organisations: cooperatives, trade unions, and workers' parties. All three organisational types played key roles in social progress, but are now in crisis.

After World War II, consumer cooperatives have lost much of their competitive advantages over other shop-owners: chain stores, central purchasing organisations, self-service stores, supermarkets, shopping centres and the like, resulting in increasing financial difficulties. A serious dilemma made itself felt: either they could merge with a regular capitalist business, become a limited liability company, or borrow substantial amounts from banks - in each case, they ceased to be autonomous cooperatives; or, they could counter the rising competition through modernisation and operational expansion - thereby increasing the considerable social distance between members and administrators, as well as further reducing involvement among the members and thereby undermining the organisation's cooperative nature (Van der Linden 2008).

Independent mass trade unions have been seriously weakened. Union density (union members as percentage of the total labor force) generally has been declining (see e.g. Van der Linden 2016). The largest umbrella organisation, the International Trade Union Confederation (ITUC), estimated in 2014 that about 200 million workers worldwide belong to trade unions, and that 176 million of these are organized in the ITUC. The ITUC also estimates that the total number of workers is roughly 2.9 billion (of whom 1.2 billion in the informal economy). Therefore, global union density currently amounts to no more than seven percent (ITUC 2014: 8). The weakness of the unions has several causes.

Firstly, the composition of the working class is changing. Unions find it difficult to 
organize employees in the service or financial sector. The rapidly growing informal economy is complicating things further, since workers change jobs frequently, and have to earn their income under often very precarious conditions. An additional factor is the "labor supply shock" (Freeman 2010) which has manifested itself since the early 1990s. Through the entry of Chinese, Indian, Russian and other workers into the global economy, there has been an effective doubling of the number of workers producing for international markets over the past two decades.

Secondly, significant economic shifts have taken place. The growth of foreign direct investment in the core countries and the semi-periphery of the world economy has been impressive, and multinational corporations and multi-state trading blocs (EU, North American Free Trade Agreement, Mercosur, etc.) have multiplied. Brazil, India, and especially China are important new players who change the rules of the game. This is accompanied by new supranational institutions, such as the World Trade Organisation, established in 1995.

Thirdly, in many countries there has been strong neo-liberal offensive against the old-style unions and their modus operandi: national legislation enfeebled trade unions, the dominant practice of collective bargaining has increasingly become decentralized, and individualized labor contracts have become much more widespread than before. Weakened trade-unions therefore have to face more and more competition from alternative structures that are better adapted to the new style labour relations. In Brazil, South Africa, the Philippines, or South Korea militant workers’ movements (social movement unions) have emerged (Scipes 2014). The ineffectivity of old-style unions is underlined by the growing tendency on the part of international trade secretariats (now called Global Unions) to engage in the direct recruitment of members in the periphery. We may think, for example, of the activities of the Union Network International (the global union for the service sector) relating to IT specialists in India.

Labor, Social Democratic, and Communist parties are generally considered to be political representatives of the working class. The oldest parties, the Social Democratic and Labor parties, 
are not doing very well electorally. All ‘classical’ parties of this type in Europe, Australia (and, in a sense, Brazil) have reached their apex in the past, at least for the time being, varying from the 1930s (Switzerland) to the early 21st century (Portugal and Brazil) (see Van der Linden 2016). More important is, though, that this family of parties is struggling with a fundamental identity problem. Social Democratic and Labour policies have since the 1930s/40s been based on two pillars: social Keynesianism and a specific 'red' party subculture with its own sports associations, women’s clubs, organisations for nature lovers, consumer cooperatives, newspapers, theatre groups, and the like.

The sociocultural and economic reversal since the 1960s/70s toppled both "pillars" of the social Keynesian stage, as the parties' subcultural networks fell to pieces and social Keynesianism became less feasible. A great many challenges had to be met more or less simultaneously. Traditional centralism had to be reconciled with basic democratic movements and feminism with the conventional androcentric culture. Moreover, the environmental movement needed to be taken seriously without abandoning the pursuit of economic growth (the condition for social redistribution in a capitalist context). Generalized confusion resulted in a tremendous increase of floating voters; ageing and decreasing membership numbers; and the virtual disappearance of active proletarian members.

Communist parties are the second major political form. For most of them the high point was in the 1940s. Now, many Communist parties are having a hard time. In quite a few countries the parties have been dissolved after electoral decline, splits or financial bankruptcy. In other countries, formerly powerful parties have lost much of their influence.

Overall we can say that on a world scale, consumer cooperatives have either not been doing well, or they have morphed into retail industries without members democratically controlling the business. Trade unions are not only a weak force, but their power is also decreasing; and in many countries trade unions have lost their natural allies, the workers' parties, 
either because these parties have disappeared or because they have adopted a variant of neoliberalism. As a consequence, INGOs and NGOs have partly shouldered activities that traditionally would have been the responsibility of the international trade union movement, such as the struggle to regulate and abolish child labour.

\subsection{Movements on the rise}

While globalisation and neo-liberal tendencies weakened traditional labour movements, these same trends had a more ambiguous impact on some other movements. The so-called second wave of feminism which manifested itself since the 1960s had generally been abating from the late 1970s or 1980s, but received a new impetus from the 1990s. In quite a few countries - but certainly not in all - the impact of feminist activities has increased. While there have been many gains for the feminist movement, as Nancy Fraser (2013) points out, many of the 'gains' have gone to support liberal (and pro-capitalist) feminist agendas that focus on women's empowerment through greater participation in the market. In contrast, some of the more radical critiques put forward by second-wave socialist feminists and others who criticized societies that over-valued paid labour and careerism, failed to acknowledge or remunerate caring labour, and imposed barriers to collective action in support of women's rights have been sidelined. At the same time, while a growing number of corporations have taken on certain aspects of the liberal feminist agenda, these initiatives are often at odds with the calls from post-colonial and other critical feminists in the Global North and South to recognize and challenge the ways in which the expansion of global 'flexibilized' capitalism and the intensification of corporate power has perpetuated forms of gendered, class-based and racialized inequality (Roberts 2015).

This version of feminism is often espoused by elite Western women and is epitomized by Facebook Chief Operating Officer Sheryl Sandberg. In her bestselling book, Lean In (2013) Sandberg urges women to achieve advancement by 'leaning in’ to demand greater recognition 
and voice in the workplace. The movement linked to this campaign (coordinated through leanin.org) has received the support of hundreds of corporate 'partners', including some of the world's largest corporations such as Coca-Cola and Pepsico, Wal-Mart, Google, Facebook and others. While much second-wave feminism (at least in the Global North) was critical of the patriarchal welfare state, which was organized around the norm of the male-breadwinner, the new corporate feminism endorses dual-earning households and the new 'flexibilised' capitalism, leaving issues of feminized carework largely unanswered and the retreat of the state from social provisioning largely unchallenged. These shortcomings take on a related but distinct form as this version of feminism is extended to the Global South where it manifests itself in terms of a business-friendly solution to the connected problems of gender inequality and poverty. Thus, while there are some progressive aspects to the notion endorsed by the World Bank (2011) and a growing number of public and private actors that gender equality is "smart economics", this has also created some foreclosures to progressive feminist action as corporate-driven development has effectively been removed as objects of critique (Roberts and Soederberg 2012).

Human rights movements have become widespread, and have enlarged their field by including economic justice and women's rights (e.g. the struggle against gender-based violence). Of special importance has been the spread of Internet: "Because the nature of human rights violations often necessitates rapid action, a tool like the internet that can provide immediate, cheap dissemination of information to a wide international audience is invaluable.” (Forsythe 2009: 188) LGBTQ movements have been doing well, and since the beginning of the millennium same-sex marriages have been granted in an increasing number of countries or certain sub-jurisdictions.

Environmentalist movements have probably never been larger than in recent years. Climate change in general and global warming in particular have been a major stimulus for mobilisation. "In the West environmental movements focus on consumption, productive use of 
natural resources and conservation or protection of natural resources.” In other parts of the world, e.g. South Asia, "such movements are based on the use of, as well as control over, natural resources.” (Puja Mondal:http://www.yourarticlelibrary.com/essay/environmental-movementsaround-the-world/31425/)

Numerous are the movements that try to protect or improve social conditions on a local level, varying from the Bolivian 'Water Wars’ of 2000, and the massive South Asian campaign against the Narmada dam, to the Argentinian piqueteros, and the Brazilian Sem Terra movement. There are also interesting consciousness-raising initiatives such as the All India People's Science Network with a membership of 700,000, which takes up public issues that are intimately related to popular needs and aspirations, such as education, health, and the environmental impact of development projects and the idea of people’s participation in development programmes; it also fights superstition and threats to secular values.

In addition, there is, what one could perhaps call, a movement for small-scale selforganisation and autonomy. Small workers' cooperatives are widespread nowadays. A report of the International Co-operative Alliance estimates that there are worldwide about 11 million workers who co-own the enterprise for which they work (Roelants, Hyungsik and Terrasi 2014: 8). Many self-employed tried to protect themselves against sickness or other adversities by founding small mutual-aid societies with a common fund that is used to help members in need. Peer-to-peer exchange and collaborative consumption initiatives (sharing economy) seem to be on the rise.

But there are also rising movements that are not necessarily progressive, and may even deflect the struggle for progress. The social void which especially labour organisations have allowed to emerge, is partly filled by religious and nationalist movements, which offer their supporters elementary forms of social security and trust networks, as well as self-esteem and clear life goals. Many poor people are drawn into such movements, in all their variants - from 
the Pentecostalist movements of Latin America and Subsaharan Africa, to Salafism in North Africa, the Middle East and Central Asia. Precarious youth in capitalist industrial cities likewise appear sometimes to be attracted to groups offering a new religious certainty. A typical example is the Hindu-fascist Shiv Sena movement, which gained influence after the defeat of the big textile workers strike in Bombay in 1980-81. The social plagues of casualisation, immiseration, increasing petty crime and trafficking made the Shiv Sainiks popular very fast. They offered the poor not only honor, status, and self-respect, but also cooperated with yellow 'trade unions,' which offered some protection (Heuzé-Briguant 1999).

\subsection{Supra-national public authorities}

The so-called globalisation process has contradictory effects on rights. Rights can be seen as claims enforced by public authorities. Unenforceable claims or claims that are privately enforced should not be considered as rights in a strict sense (Hohfeld 1978). Some scholars believe that the current changes "threaten all rights embedded in states, including workers' rights" (Tilly 1995: 6). Other scholars have stressed that globalisation is not replacing the state. "If globalization has reduced the state's power in one respect, the process has made the state more indispensable in another, that is as the central mechanism for redistributing the social income between social classes and regions." (Hobsbawm 1995: 43) It has been pointed out that "the threats to workers' rights taking place in the high-income countries as a result of globalization are not necessarily paralleled in countries where the welfare state hardly has been built. Transnational investment in fact has thrived on the existing lack of workers' rights in export-processing zones." (Benería 1995: 47) Under certain circumstances globalisation can even generate pressures in favour of workers' rights, for instance when workers in advanced countries feel threatened by the competition of their fellow workers in low-wage countries.

In any case, rights are only rights if a public (national or international) authority is capable and willing to enforce them. In the field of labour rights, for example, the International Labour 
Organisation is a crucial institution. Its conventions, if ratified by member states, are guidelines for good practices at shopfloor level. However, two weak spots of the ILO have to be stressed. Not only is the ILO a relatively powerless organisation; it is also rather slow in its response to new developments. The ILO could therefore use some streamlining, but more importantly, it could use additional competences. A necessary first step would be that the ILO should be given the possibility to further develop its monitoring and reviewing capacity. The ILO case illustrates that, because rights are publicly enforceable claims and states are losing some of their guaranteeing capacity, bigger innovations are required. We will then need more powerful international agencies as guarantors of social rights.

\section{Challenges and possibilities for social progress}

Ever since it came onto the agenda the notion of social progress has been hotly contested and always controversial. Many people have had good reason to deny its pertinence, while others contest its assumed positivity. Current doubts and ambivalence are not unique, beliefs in the existence and/or the possibility of progress have always had their historical ups and downs. In contemporary history, a period of strong belief in social progress and high hopes for its continuance was the era running from about 1950 to 1980, in spite of being lived under the risk of a thermonuclear Third World War. It was the time of the arrival of mass consumption and of the extension of social rights in the well off quadrant of the world. In Asia and Africa it was the time of national independence movements coming to fruition through the "New Emerging Forces” of the Bandung meeting. In Latin America it was the years when the high modernist capital city Brasilia was built, and when new futures were proclaimed, on the one hand by the Cuban revolution and on the other by the "Alliance for Progress". It was the moment of triumph and a peak of strength of mass social movements firmly believing in progress in the North, of national liberation movements in Asia and Africa, of trade unions and workers parties in the 
developed capitalist world, and of the Communist movement, for a while basking in the glory of the Sputnik and the spread to Asia and Latin America.

That world of the recent past, however, is now bygone. This is not the place to explain why, but we have to highlight how the stage for debates and struggles of progress has changed dramatically to give us the situation we face today. A historical conjuncture favourable for social progress includes four crucial pillars: a vision of a positively different society; inclusive institutions and/or mass movements for collective identity and action; widespread individual resources and freedom of action; and movements of the "damned of the earth", i.e., of the socially disadvantaged. A belief in progress needs a horizon of an achievable better world. It requires an inclusive social vehicle with room for the mass of the population to reach this better world. This belief is further strengthened and sustained by a large number of individuals experiencing a sense of empowerment. Finally, for social progress to be general, nobody should be left out, which requires individual empowerment and collective action by the most disadvantaged.

In the post-World War II period, there were the visions of coming mass consumptioncum-upward social mobility, of welfare states with extensive social rights, of national liberation, and of socialism. The national welfare and developmental states were inclusive institutions, and so were the labour and nationalist movements sustaining or fighting for them. The spread of education, at different levels in different parts of the world, urbanization, and industrialization provided individual opportunities, Labour movements, Feminism, Latin American populism, and national liberation and civil and human rights movements mobilized and organized the disadvantaged, including the most vulnerable.

Today socialism has largely disappeared from the horizon (except to some extent in Latin America) and the still existing welfare states are struggling to maintain themselves. Discretionary consumption and a middle-class life have become discernible to large, but still 
mostly minoritarian populations of Asia, Latin America and Africa, but outside East Asia it is not (yet) widely convincing. In Europe, North America, and Japan these prospects no longer inspire or hold out much hope for people. On the contrary, for a growing number of younger people in particular, middle-class consumerism is appearing increasingly fragile or elusive.

The inclusivity of the nation-state is challenged, in different ways, from two sides, from the mobility of capital and from the mobility of labour. The former constrains the economic resources of the state, the latter complicates and sometimes disrupts the existing concept of citizenship. Many inclusive popular mass movements and organizations have been eroded or fragmented. Explicitly exclusivist movements and currents, ethnic and religious, have seen a considerable resurgence and even seize the state.

Significant minorities are holding two opposite and delimited visions of a different future. One is focused on technological advances only without any perspective of broad social progress, another is envisaging a society of no growth and of reduced consumption in the rich countries as the only way to avert a climate catastrophe. In this situation, what could be a realistic vision of social progress?

One credible and unifying vision of social progress might be that of universalizing and advancing human capability._We noticed at the outset of this chapter that because of revolutionary technological and biomedical advances, economic development, long-term social inclusion, through cutting down (if by no means doing away with) ancient institutionalized racism and sexism, and because of a huge growth of ecological and climate knowledge, humankind is standing at a historical peak of its possiblities. Social progress will mean realizing these possibilities.

The crucial inclusive institution has to be global in order to be able to face up to the challenges of the planetary ecosystem as well as of universalizing the capability of every human being. For the foreseeable future, this global institution is unlikely to look like a cosmopolitan 
world. Rather, it will be a human community of nations. Currently, however, not even that is a short-term realizable prospect. Nations are increasingly divided economically and are ideologically polarized. Most nations are in need of reconstitution and an awareness of global challenges might contribute to it. What will happen to the existing global climate agreements will be the most pertinent indicator of progress in this respect.

Global and regional international institutions are stronger and more influential than fifty or twenty-five years ago, the United Nations and its family of specialized organizations, the Group of Twenty, the European Union, the African Union, the Association of Southeast Asian Nations, the Community of Latin American and Caribbean States, etc. There is also a wider and denser net of globally networked social movements and of humanitarian and human rights NGOs. There are more NGOs working for global inclusion and public goods than ever before. But there are also new and increasingly active exclusivist currents in the world. Some global steps against international tax havens and money laundering are being discussed at international levels of power, but not even embryonically is there a global institution in sight for regulating the world economy- i.e., global capitalism- in a direction of human equality and the planetary common good.

Individual empowerment is expanding with extended education and extra-local digital connectivity, providing wider opportunities for women in most parts of the world, and generating international youth and children's cultures. But this enpowerment is often hemmed in by increasing social segmentation and mounting employment crises.

New movements for collective empowerment of the most disadvantaged have emerged, of indigenous peoples, of informal workers, of urban slum-dwellers, for example. But they are usually much weaker than the great labour and liberation movements of the past. Indeed, the informalization and precarization of work, with their denial or minimization of workers' rights seems be the predominant tendency. 
In conclusion, a re-launch of global social progress in tandem with technological and biomedical advances- i.e. a new Great Transformation- is not beyond the realms of possibility even though its short-term prospects look modest. Inclusive global institutions, sustained by inclusive global movements and networks, increased individual empowerment worldwide, by education, connectivity and stronger health, and organizational rights and possibilities for the world's most disadvanraged are prerequisites. They are all aimed at universalizing human capability. Both old and new social movements will be part of this seemingly utopian enterprise and there will be both national and regional tendencies also pointing towards social transformation. 


\section{References}

Anderson, Bridget (2007). "A Very Private Business: Exploring the Demand for Migrant Domestic Workers." European Journal of Women's Studies 14 (3): 247-64.

Arat-Koç, Sedef (2006). “Whose Social Reproduction? Transnational Motherhood and Challenges to Feminist Political Economy.” In: Social Reproduction: Feminist Political Economy Challenges Neo-Liberalism, eds. Meg Luxton and Kate Bezanson, 75-92. Montréal \& Kingston: McGill-Queen’s University Press.

Asian Development Bank (2011). The Role of the Middle Class in Economic Development: What Do Cross-Country Data Show. http://www.adb.org

Beck, Ulrich (2000). The Brave New World of Work, Cambridge, Polity Press.

Benería, Lourdes (1995). "The Dynamics of Globalization", International Labor and WorkingClass History, No. 47 (Spring): 45-52.

Bowen, A and Hepburn, C (2013). 'Prosperity with growth: Economic growth, climate change and environmental limits’, in R. Fouquet (ed.), Handbook on Energy and Climate Change, Edward Elgar.

http://www.worldbank.org

Brenner, R. (2002). The Boom and the Bubble: The U.S. in the World Economy. NewYork: Verso.

Carothers, T. and Youngs, R. (2015). The Complexities of Global Protests. Washington: Carnegie Foundation.

Casassas, D., P. Wagner (eds.). 2016. Modernity and Capitalism, special issue of European Journal of Social Theory 19 (2).

Case, A. and Deaton, A. 2015. 'Rising morbidity and mortality among White non-Hispanic Americans in the $21^{\text {st }}$ century', PNAS, 112, no. 49. www.pnas.org/cgi/doi/10.1073 
Castells, M. (2010). End of Millennium, 2nd edition with a new preface. Chichester, UK: Wiley Blackwell.

Castles, S., De Haas, H., Miller, M. (2014). The Age of Migration: International Population Movements in the Modern World (Fifth Edition). New York: Guilford Press.

Connell, R.W. (1995). Masculinities. Berkeley: University of California Press.

Cruz, M., Foster, J., Quilinn, B., and Schellekens, Ph. (2015). “Ending Extreme Poverty and Sharing Prosperity: Progress and Policies”, World Bank Policy Research Note. http://www.worldbank.org

Delgado Wise, R. and D. Martin (2015). ‘The Political Economy of Global Labour Arbitrage’, in Kees van der Pijl (ed.), Handbook of the International Political Economy of Production, Edward Elgar Publishing.

Ehrlich, P. and J. Holden (1971), 'Impact of population growth’, Science, 171 (3977): 12121217.

Elson, Diane (2010). "Gender and the Global Economic Crisis in developing countries: A Framework for Analysis." Gender and Development 18 (2): 201-12.

European Women's Lobby (2012). The Price of Austerity: The Impact on Women's Rights and Gender Equality in Europe. Brussels: European Women's Lobby.

Fleurbaey, Marc and Didier Blanchet (2013). Beyond GDP. Measuring Welfare and Assessing Sustainability. Oxford: Oxford University Press.

Forsythe, David P. (ed.) (2009). Encyclopedia of Human Rights, vol. 5. Oxford: Oxford University Press.

Fortune (2015). Global 500, Retrieved from http://fortune.com/global500/. Fraser, Nancy (2013). Fortunes of Feminism: From State-managed Capitalism to Neoliberal Crisis. London: Verso. 
Freeman, Richard (2010). “What Really Ails Europe (and America): The Doubling of the Global Labor Force”, The Globalist, March 5.

Fukuyama, Francis (1992). The End of History and the Last Man. New York: Avon Books.

Glaser, Bernhard, ed. (1987). The Green Revolution Re-Visited: Critique and Alternatives. London: Allen \& Unwin.

Gordon Robert J. (2016). The Rise and Fall of American Growth. Princeton and Oxford: Princeton University Press.

Harvey, David (2003). The New Imperialism, Oxford: Oxford University Press.

Heuzé-Briguant, Gérard (1999). “Populism and the Workers Movement: Shiv Sena and Labour in Mumbai”, South Asia: Journal of South Asian Studies, 22, 2 (December): 119-148.

Hobsbawm, Eric (1995). "Guessing About Global Change", International Labor and WorkingClass History, No. 47 (Spring): 39-44.

Hochschild, Arlie Russell (2000). "The Nanny Chain." American Prospect 11 (4): 32-36.

Huang, S., et al. (2005). Asian Women as Transnational Domestic Workers. Singapore: Marshall Cavendish Academic.

Huang, Shirlena, et al. (eds.) (2012). Global Networks. Special Issue: Transnational Mobilities for Care: Rethinking the Dynamics of Care in Asia. Oxford and Malden MA: Blackwell.

ILO (2006) Changing Patterns in the World of Work. Geneva: International Labour Office.

ILO (2012)The Global Employment Trends for Women. Geneva: International Labour Office.

ILO (2014) World of Work Report. Developing with Jobs. Geneva: International Labour Office.

ILO (2015) World Employment Social Outlook. The changing Nature of Jobs. Geneva: International Labour Office.

Iredale, Robyn, et al. (eds.) (2002). Return Skilled Migration and Business Migration and Social Transformation. Wollongong: Centre for Asia Pacific Social Transformation Studies. 
ITUC (2014). Building Workers’ Power. Congress Statement. Berlin: International Trade Union Confederation.

Kabeer, Naila (2015). “Gender, Poverty, and Inequality. A Brief History of Feminist Contributions in the Field of International Development”. Gender and Development, special issue: Inequalities. 23 (2): 189-205.

Kannan, K.P. (2014). Interrogating Inclusive Growth: Poverty and Inequality in India. Routledge: New Delhi and Oxon.

Kannan, K.P. (2016). “At the Bottom of Durable Inequality: The Status of India’s Dalits and Adivasis”. Paper presented at the Collective Book Workshop, Department of Anthropology, London School of Economics, June 30-July 1, London.

Kochhar, R and Richard Fry (2014). "Wealth Inequality has Widened along Racial, Ethnic Lines since the End of Great Recession”. Pew Research Center, December 12.

Kofman, Eleonore (2012). “Rethinking Care Through Social Reproduction”, Social Politics, 19 (1): 142-162.

Lefebvre, Henri (1991). The Production of Space. Oxford: Blackwell.

Levine, Robert S, James E Foster, Robert E Fullilove, Mindy T Fullilove, Nathaniel C Briggs, Pamela C Hull, Baqar A Husaini and Charles H Hennekens (2001). “Black-White Inequalities in Mortality and Life Expectancy, 1933-1999: Implications for Healthy People 2010”, in Public Health Reports, Vol. 116, September-October: 474-483.

Lindert, P.H. and Williamson, J.G. (2016). Unequal Gains. Princeton and Oxford: Princeton University Press.

Maddison, A. (2007). Contours of the World Economy, 1-2030 AD. Oxford: Oxford University Press.

Martinelli, Alberto (2005). “From World System to World Society?”, Journal of World-Systems Research, 11, 2 (December): 241-260. 
Mayer, Arno (1985). The Persistence of the Old Regime. Europe to the Great War. New York: Pantheon.

McKinsey Global Institute (2013). Financial Globalization. Retreat or Reset? McKinsey \& Co. (June). Retrieved from http://www.mckinsey.com/global-themes/employment-andgrowth/financial-globalization.

Milanovic, Branco (2013), “Global Income Inequality in Numbers: in History and Now”, Global Policy, 4 (2), May: 198-208.

Milanovic, Branko (2016). Global Inequality. Cambridge, Mass.: The Belknap Press of Harvard University Press.

Munck, Ronaldo (2016a). “Global Sociology: Towards and Alternative Southern Paradigm”, International Journal of Politics, Culture and Society. 29 (3): 233-249.

Munck, Ronaldo (2016b) ”Globalisation, Labour and the Precariat: old wine in new bottles?”, in C. Schierup and M. B. Jorgensen (eds). The Politics of Precarity. Migrant Conditions, Struggles and Experiences. Leiden and Boston: Brill: 78-98.

Nayyar, Deepak (2013). Catch Up. Oxford: Oxford University Press.

Ohmae, Kenichi (1995). The End of the Nation-State: The Rise of Regional Economies. New York: Simon and Schuster Inc.

Olzhansky, J. et al. (2012). "Differences in life expectancy due to race and educational differences are widening and may not catch up”, Health Affairs 31(8): 1803-1810. Oxfam (2017). An Economy for the 99\%. Oxfam Briefing Paper. Piketty, Thomas (2014). Capital in the Twenty-First Century, Harvard University Press. Polanyi, Karl (1944). The Great Transformation, New York: Farrar \& Rinehart. Putnam, Robert D. (2015). Our Kids. New York: Simon \& Schuster. Ranis, Gustav, Frances Stewart and Alejandro Ramirez (2000). “Economic Growth and Human Development”, World Development, 28 (2): 197-219. 
Reis, Elisa (2004). “The Lasting Marriage between State and Nation despite Globalization”, International Political Science Review, 35 (3): 251-257.

Roberts, Adrienne, and Susanne Soederberg (2012). "Gender Equality as Smart Economics? A Critique of the 2012 World Development Report". Third World Quarterly 33 (5): 949-968. Roberts, Adrienne (2015). "The Political Economy of 'Transnational Business Feminism': Problematizing the Corporate-Led Gender Equality Agenda." International Feminist Journal of Politics, 17 (2): 209-231.

Roelants, Bruno, Eum Hyungsik and Elisa Terrasi (2014). Cooperatives and Employment. A Global Report. Brussels: International Co-operative Alliance.

Sandberg, Sheryl (2013). Lean in: Women, Work, and the Will to Lead. New York: Random House.

Scipes, Kim (2014). "Building Global Labor Solidarity Today: Learning from the KMU of the Philippines”, Class, Race and Corporate Power, 3 (1), Article 4. (http://digitalcommons.fiu.edu/classracecorporatepower/vol3/iss1/4).

Smith, Jackie (2005). “Exploring Connections between Global Integration and Political Mobilization”, Journal of World-Systems Research, 11, 2 (December): 255-285.

Strange, Susan (1996). The Retreat of the State: The Diffusion of Power in the World Economy. Cambridge: Cambridge University Press.

Sturgeon, T.J. (2003), "What Really Goes on in Silicon Valley? Spatial Clustering and Dispersal in Modular Production Networks”, Journal of Economic Geography, 3 (2): 199-225.

Theodoru, Angelina E. and Aleksandra Sandstrom (2015). "How Abortion is Regulated Around the World”, Pew Research Center (available online at http://www.pewresearch.org/facttank/2015/10/06/how-abortion-is-regulated-around-the-world/).

Therborn. Göran (2004). Between Sex and Power. Family in the World, 1900-2000. London: Routledge. 
Therborn, Göran (2006). Inequalities of the World. London: Verso.

Tilly, Charles (1995). “Globalization Threatens Labor’s Rights”, International Labor and Working-Class History, No. 47 (Spring): 1-23.

Tilly, Charles (1999), Durable Inequality. Berkeley: University of California Press.

Tschakert, P. (2016).”The Role of Inequality in Climate-Poverty Debates”, World Bank Policy Research Working Paper 7677. http://www.worldbank.org

UN (2015a). The Millennium Development Goals Report. http://www.un.org

UN (2015b). World Population Prospects. The 2015 Revision, New York. http://esa.un.org/unpd/wpp/

UN Population Division (2009). International Migrant Stock: The 2008 Revision. New York: UN Population Division. Available online.

UNCTAD (2015). International Trade and Development Statistics, United Nations, Geneva. Available online.

UNDP (2009). Human Development Report 2009: Overcoming Barriers: Human Mobility and Development. New York: United Nations Development Programme. http://hdr.undp.org/en/reports/global/hdr2009/

UNDP (2014). Human Development Report 2014. New York: United Nations Development Programme.

UNDP 2015. Human Development Report 2015. New York: United Nations Development Programme. http://www.undp.org

UNFPA (2015). State of the world's population 2015. New York: United Nations Population Fund. http://www.unfpa.org

Van der Linden, Marcel (2008). Workers of the World. Essays toward a Global Labor History. Leiden and Boston: Brill. 
Van der Linden, Marcel (2016). “Global Labour: A Not-so-grand Finale and Perhaps a New Beginning”, Global Labour Journal, 7, 2 (May): 201-210.

Wagner, Peter (2016). “Democracy and capitalism in Brazil, South Africa and Europe,” in G. Rosich, P Wagner (eds.), The Trouble with Democracy. Political Modernity in the 21st Century. Edinburgh: Edinburgh University Press.

Walzer, Michael (1994). Thick and Thin: Moral Argument at Home and Abroad. Notre Dame, IN: University of Notre Dame Press.

Weiss, Linda (1998). The Myth of the Powerless State. Ithaca: Cornell University Press.

WHO (2015). World Health Statistics 2015. Geneva: World Health Organisation.

\section{http://www.who.org}

World Bank (2008). World Development Indicators Database, Retrieved from http://www.maoner.com/GDP.pdf.

World Bank (2011). World Development Report 2012: Gender Equality and Development. Washington, DC: The International Bank for Reconstruction and Development/The World Bank.

World Bank (2012). Turn down the heat: why a $4^{\circ} \mathrm{C}$ warmer world must be avoided. Washington DC : World Bank. Retrieved from http://documents.worldbank.org/curated/en/2012/11/17097815/turn-down-heat-4\%C2\%B0cwarmer-world-must-avoided

World Bank (2013). World Development Indicators. Washington, DC: World Bank. World Bank (2015), World Development Indicators. Washington, DC: World Bank. World Co-operative Monitor (2015). Brussels: International Co-operative Alliance. www.monitor.coop

Xing, Y. and Kolstad C. (2002). “Do Lax Environmental Regulations Attract Foreign Investment?’ Environmental and Resource Economics”, 21 (1): 1-22. 
Yeates, Nicola (2012). "Global Care Chains: A State-of-the-Art Review and Future Directions in Care Transnationalization Research", Global Networks 12 (2): 135-154. 